\title{
LncRNA-ENST00000543604 Exerts a Tumor-Promoting Effect via miRNA 564/AEG1 or ZNF326/EMT and Predicts The Prognosis of and Chemotherapeutic Effect in Colorectal Cancer
}

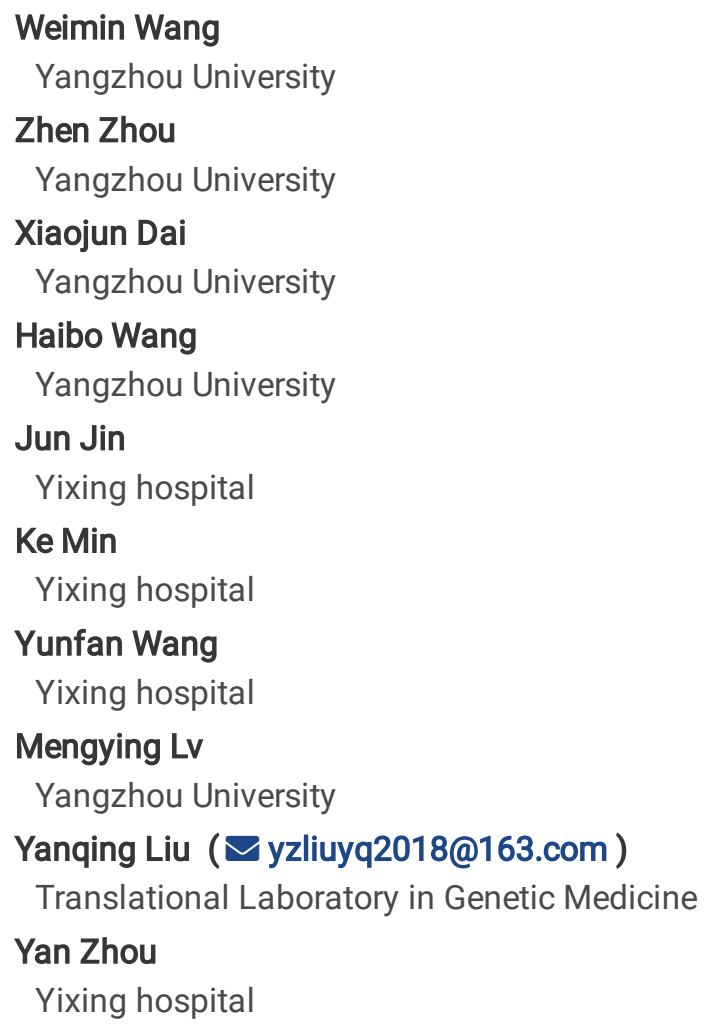




\section{Abstract}

Background:

Colorectal cancer is a common malignant tumor. Recent studies have found that IncRNAs play an important role in the occurrence and development of colorectal cancer.

Methods:

Based on high-throughput sequencing results of fresh CRC tissues and adjacent tissues, we identified IncRNA-ENST00000543604 (IncRNA 604) as the research object by qRT-PCR in CRC tissues and cells. The FISH method was used to detect the location of IncRNA 604 in cells, and its expression was detected on a tissue chip. We explored the mechanism of IncRNA 604 action by using luciferin reporter, qRT-PCR and Western blot assays. Kaplan-Meier survival analysis and a Cox regression model were used to analyze the correlation of IncRNA 604 and its regulatory molecules with the prognosis of and chemotherapy efficacy in CRC patients.

Results:

In this study, we found that the expression levels of IncRNA 604 were increased in CRC. LncRNA 604 could promote CRC cell proliferation and metastasis through the miRNA 564/AEG-1 or ZNF326/EMT signaling axis in vivo and in vitro. LncRNA 604 could predict the prognosis of CRC and was an independent negative factor. LncRNA 604 exerted a synergistic effect with miRNA 564 or ZNF326 on the prognosis of CRC. LncRNA 604 could improve chemoresistance by increasing the expression of AEG-1, NF-KB, and ERCC1.

Conclusions:

Our study demonstrated that IncRNA 604 could promote the progression of CRC via the IncRNA 604/miRNA 564/AEG-1/EMT or IncRNA 604/ZNF326/EMT signaling axis. LncRNA 604 is an independent and effective molecule for predicting the prognosis of CRC. LncRNA 604 could improve chemoresistance by increasing drug resistance protein expression.

\section{Background}

Colorectal cancer (CRC) is a common malignant tumor in the digestive tract, and its incidence ranks third among malignant tumors worldwide, making it a worldwide health concern [1]. The prognosis of CRC mainly depends on early diagnosis and timely surgical treatment: the prognosis is better if the cancer is only confined to the intestinal wall and the prognosis is poor for those patients with extensive cancer invasion and distant metastasis [2]. The pathological process of tumor metastasis mainly involves tumor cells spreading from the primary tumor microenvironment to various remote organs and colonizing other sites [3]. Despite the popularity of early tumor screening and continuous improvement in treatment, the mortality rate of CRC has decreased in recent years, and metastasis of CRC is still a key factor that causes low clinical efficacy, short survival and poor prognosis [4]. Therefore, it is necessary to identify and target oncogenes and tumor suppressor genes involved in the metastasis of CRC to inhibit this process and predict the chemotherapy efficacy and prognosis of CRC patients.

In addition to protein-coding genes that could regulate tumor invasion and metastasis, there are also some noncoding genes involved in this process. Noncoding RNAs mainly include small noncoding RNAs and long-chain noncoding RNAs (IncRNAs). LncRNA refers to a transcript that is longer than $200 \mathrm{nt}$, lacks an open reading frame, and does not have protein coding functions. LncRNA dysfunction is related to a variety of diseases [5]. The abnormal expression of IncRNAs is directly related to the occurrence and development of many malignant tumors [6, 7]. With the development of transcriptomics analysis technology, we have found that IncRNAs are related to a series of biological processes, including chromatin modification, transcription interference, alternative splicing, translation initiation, and miRNA decay $[8,9]$. LncRNAs can interact with proteins, RNAs and lipids and play a key mediating role in the occurrence and development of cancer $[10,11]$. LncRNAs have become an important part of transcription and epigenetic regulatory networks. 
In recent years, differentially expressed IncRNA profiles in CRC tissues and adjacent tissues have been reported. Some IncRNAs, such as IncRNA-ATB and DANCR, could be effective markers for predicting the prognosis of CRC [12.13]. LncRNA-422 and BC032913 can regulate downstream target genes through different mechanisms to affect the proliferation or invasion of CRC cells $[14,15]$. To identify more IncRNAs in the occurrence and development of CRC, we selected 3 fresh human-derived CRC tissues and corresponding adjacent tissues to detect the expression levels of IncRNAs by high-throughput sequencing. The sequencing results showed that there were 3006 differentially expressed IncRNAs compared with adjacent tissues. According to the copy difference of these IncRNAs that were greater than or equal to 10, the expression of IncRNAs was determined in fresh CRC tissues and adjacent tissues, CRC cells and intestinal mucosal cells. Finally, IncRNA-ENST00000543604 (IncRNA 604) was preliminarily identified as having biological functions through a high-content screening experiment, and the expression of IncRNA 604 was relatively stable in CRC tissues and cells.

In our article, we constructed virus expressing high levels and low levels of IncRNA 604 to systematically study its function. Simultaneously, we used a CRC database tissue chip to study whether IncRNA 604 and its regulatory molecules could predict the prognosis of and chemotherapy efficacy in CRC patients.

\section{Materials And Methods}

\section{Clinical specimens}

A total of $470 \mathrm{CRC}$ patients undergoing surgical resection were enrolled from Yixing Hospital affiliated with Yangzhou University Medical College from 2009.01 to 2015.12. All patients provided informed consent. These patients were followed up for at least 5 years, and their pathological diagnosis was confirmed by two pathologists. The clinicopathological characteristics are presented in Table S1. The procedures of this study were approved by the Ethics Committee of Yixing Hospital and were performed according to the principles of the Declaration of Helsinki.

\section{Cell lines and animals}

The human CRC cell lines SW620, HCT116, HT29, SW480, RKO, HCT-15 and FHC were purchased from Wuhan Procell Life Science and Technology Co., Ltd. They were cultivated in RPMI-1640 medium supplemented with 10\% FBS and 1\% penicillin/streptomycin at $37^{\circ} \mathrm{C}$ and $5 \% \mathrm{CO}_{2}$.

Four-week-old female BALB/c nude mice were obtained from the Comparative Medicine Laboratory Animal Center [License No. scxk (SU) 2012-0004] of Yangzhou University and maintained under specific pathogen-free conditions. Animal studies were performed in accordance with the National Institutes of Health Guide for the Care and Use of Laboratory Animals.

\section{Lentiviral infection and generation of stable cell lines}

HCT116 and HT29 cells were infected with lentivirus (LV)-IncRNA 604, LV-IncRNA 604-ctrl, LV-IncRNA 604-RNA interference (RNAi) and LV-IncRNA 604-RNAi-ctrl at a multiplicity of infection (MOI) of 20 and $10 \mu \mathrm{g} / \mathrm{ml}$ polybrene (Shanghai GeneChem Co, Ltd.).

After lentiviral infection for $8 \mathrm{~h}$, these cells were maintained with normal RPMI-1640 medium for $24 \mathrm{~h}$. Subsequently, these cells were incubated in RPMI-1640 with $2 \mu \mathrm{g} / \mathrm{ml}$ puromycin (Gibco-BRL, Gaithersburgh, MD, USA). The knockdown and overexpression efficiency of IncRNA 604 was further analyzed by RT-PCR.

\section{Construction of a Tissue Microarray (TMA) and Immunohistochemistry}

First, we used HE staining to examine the cancer tissues and corresponding adjacent tissues. Then, we used Shanghai Xinchao Biological Co., Ltd. to make TMAs. These TMAs were stored at $-20^{\circ} \mathrm{C}$ for later use.

The immunostaining protocol was performed according to a previously published article [16]. Rabbit monoclonal anti-ZNF326 antibody (1:100, ABclonal Technology, USA) was incubated at $4^{\circ} \mathrm{C}$ overnight. The staining of ZNF326 in tissue was scored by two pathologists and evaluated by the semiquantitative immunoreactivity score (IRS), as reported elsewhere [17].

\section{CCK8 assay}

Page $3 / 24$ 
HCT116 or HT29 cells $\left(0.5 \times 10^{3}\right.$ cells per well) were seeded in 96-well plates. After treatment, cell growth was detected by Cell Counting Kit-8 (CCK-8) solution (Dojindo Molecular Technology Inc., Shanghai, China) at five time points (24, 48, 72, 96 and $120 \mathrm{~h}$ ). The absorbance was measured at $450 \mathrm{~nm}$ by an automatic microplate reader.

\section{EdU immunofluorescence assay}

HCT116 or HT29 cells were cultured to logarithmic growth. Then, $5 \times 10^{3}$ cells/well were seeded in a 96-well plate. After $24 \mathrm{~h}$, immunofluorescence analysis was performed according to the protocol of the EdU Kit (RIBOBIO CO, LTD, Guang Zhou, China).

\section{Cell migration and invasion assay}

The upper chambers of a Transwell chamber were coated or not with Matrigel (Millipore, Billerica, MA, USA) with serum-free RPMI 1640 medium at a ratio of $1: 2$. The cells were resuspended to $5 \times 10^{5}$ cells $/ \mathrm{ml}, 100 \mu \mathrm{l}$ cell suspension was added to the upper chamber, and $600 \mu \mathrm{l}$ RPMI 1640 medium containing 10\% FBS was introduced into the lower chamber. After $24 \mathrm{~h}$ of incubation, the cells were fixed with $4 \%$ formaldehyde for 10 min and stained with $0.1 \%$ crystal violet for 5 min. The number of penetrating cells was recorded in five fields of view under an inverted microscope, and the cells were photographed.

\section{High-Content Imaging System Analysis}

HCT116 or HT29 cells were seeded in a 96-well plate at a density of $5 \times 10^{3}$ cells/well and further cultured for $24 \mathrm{~h}$. The 96 -well plate was placed into a PerkinElmer Operetta CLS high-content imaging analysis system (PerkinElmer, Waltham, USA). Last, for a 12-h observation, Harmony 4.1 software was used to obtain and analyze the data.

\section{Fluorescence in situ hybridization (FISH)}

The TMA paraffin sections were baked overnight at $65^{\circ} \mathrm{C}$. Xylene was deparaffinized twice. The sections were incubated at $100^{\circ} \mathrm{C}$ for $25 \mathrm{~min}$, digested in pepsin solution for $15 \mathrm{~min}$, and then washed with anhydrous ethanol. Two microliters of probe mixture was dropped on the sections after the above treatment, covered with glass, and sealed with rubber glue. These sections were placed in a hybridizer, denatured at $85^{\circ} \mathrm{C}$ for $5 \mathrm{~min}$, and hybridized at $37^{\circ} \mathrm{C}$ overnight. The slides were incubated in eluent for $5 \mathrm{~min}$ at $37^{\circ} \mathrm{C}$, rinsed with $70 \%$ ethanol and dried naturally. After staining with $5 \mu \mathrm{DAPI}$, the cells were observed under a fluorescence microscope.

The immunofluorescence value at each point in the tissue chip was calculated by Image-Pro Plus 6.0 software (Media Cybernetics, Inc., Rockville, MD, USA). The average optical density (AO) = cumulative optical density value (IOD)/pixel area of tissue (AREA). A higher $\mathrm{AO}$ value indicated a higher positive expression level.

\section{Quantitative real-time PCR (qRT-PCR)}

RNA from tissues and cells was isolated using TRIzol reagent (Invitrogen, USA) according to the manufacturer's manual. The purified RNA was reverse synthesized into cDNA using the PrimeScript RT reagent Kit (Takara Biotech, Dalian, China). Then, we used SYBR Green Real-Time qPCR analysis (Roche Applied Science, Penzberg, Upper Bavaria, Germany) to analyze the transcriptional cDNA.

The sequences of the primers were as follows (5'-3'): IncRNA 604-F, AAAGAGAGCAAGAGGAGATCAAATC and IncRNA 604-R, CCAGGTCTCCACCCTTATGG (GUANGZHOU RIBOBIO CO., LTD, China); AEG-1-F, CGGAGCGAGGAACAGAAGAAGAAG and AEG-1-R, AACCAGAATCAGTCAGCACCTTATCAC; NF-kB-F, GGTGGACTACCTGGTGCCTCTAG and NF-kB-R, CGCCTCTGTCATTCGTGCTTCC; ERCC1-F, CTGCTGCTGCTGCTGCTTCC and ERCC1-R, GCTCCCACATCCACCAAGAAGAAG; GAPDH-F, ACGGATTTGGTCGTATTGGG and GAPDH-R, CGCTCCTGGAAGATGGTGAT (Sangon Biotechnology Inc., Shanghai, China). The relative expression level of transcripts was normalized to that of the internal control GAPDH and analyzed by using the $2^{\wedge}-\Delta \Delta C t$ method.

\section{Western blot}

Using the BCA method to determine the protein concentration, $100 \mu \mathrm{g}$ protein was added to $7.5 \%$ SDS-PAGE for analysis. Then, the protein was transferred to a PVDF membrane after electrophoresis, blocked in TBST solution containing 5\% skimmed milk powder, and incubated with antibody. The protocols were performed as previously described [18]. The monoclonal rabbit anti-ZNF326 
(1:1000, ABclonal Technology, USA), monoclonal rabbit anti-E-cadherin (1:1000, Cell Signaling Technology California, USA), monoclonal rabbit anti-N-cadherin (1:1000, Cell Signaling Technology California, USA), monoclonal rabbit anti-Vimentin (1:1000, Cell Signaling Technology California, USA), monoclonal rabbit anti-AEG-1 (1:1000, Abcam, England), monoclonal rabbit anti- NF-KB (1:1000, Cell Signaling Technology California, USA), monoclonal rabbit anti-ERCC1 (1:1000, Abcam, England), and monoclonal mouse anti- $\beta$-actin antibody (1:2000; Beyotime Biotechnology, Nantong, China) were used as primary antibodies. ImageJ software (version 1.44, Wayne Rasband, National Institutes of Health, USA) was applied to quantify the correction of these protein bands with the corresponding $\beta$-actin level.

\section{Double luciferase reporter assay}

The cells were divided into 24-well culture plates the day before plasmid transfection. We cloned the targeted and mutant sequences of IncRNA 604 and AEG-1 into the pmirGLO vector. According to the experimental design group, plasmid transfection experiments were performed by Lipofectamine 2000 (Invitrogen). After $24 \mathrm{~h}$ of transfection, the expression of fluorescent marker genes in the cells was observed under a fluorescence microscope, and then the Dual-Luciferase ${ }^{\circledR}$ Reporter Assay System (E1910, Promega) kit was used to process the cells and detect luciferase expression. All experimental data were from three independent experiments.

\section{RNA pull-down and mass spectrometry analysis}

Based on the PINK1-AS gene sequence, PCR was performed with plasmid DNA as a template to obtain the full-length sequence containing the T7 promoter. LncRNA 604 sense and antisense primer sequence probes were obtained and labeled with biotin. Then, the labeled RNA probe was incubated with the protein extract to form an RNA-protein complex. This complex was incubated with Pierce Nucleic-Acid Compatible Streptavidin Magnetic Beads for 30 min, eluted with biotin elution buffer, added to 5x SDS PAGE loading buffer, and transferred to ice immediately after boiling. Subsequently, we used SDS-PAGE for electrophoresis, stopped the electrophoresis $1 \mathrm{~cm}$ from the separation gel and cut off the gel. The gel was analyzed by mass spectrometry.

\section{In vivo assays}

In the tumor xenograft model, approximately $2 \times 10^{6} \mathrm{HT} 29$ stable cells and negative control cells ( $\left.0.2 \mathrm{ml} / \mathrm{mouse} ; 5 \mathrm{mice} / \mathrm{group}\right)$ were implanted subcutaneously into the flanks of each mouse. The tumors were photographed each week, and after 21 days, the mice were sacrificed.

For the metastasis experiments, HT29 stable cells were injected into the abdominal cavity and tail veins of the mice $(n=5)$. In the abdominal metastasis model, $\mathrm{HT} 29$ stable cells were set as $0.2 \mathrm{ml} / 2 \times 10^{5} /$ mouse. The peritoneal metastases were observed and photographed each week. In the tail vein metastasis model, we adjusted the concentration of HT29 stable cells to $2 \times 10^{4} / \mathrm{ml}$ and then administered $0.2 \mathrm{ml}$ cell suspension into the tail veins. After 40 days, the metastases were photographed. At each time point of observation, $150 \mathrm{mg} / \mathrm{kg}$ D-luciferin (Gold Biotech, USA) was injected into the abdominal cavity of nude mice for 10 min, and then photographs were taken by a small-animal living imaging system (PerkinElmer, USA).

All animal experiments were conducted in accordance with the Committee of YangZhou University for the Use and Care of Animals.

\section{Statistical analysis}

All data were collected and analyzed using SPSS (version 21.0) and STATA (version 10.1) software. The basic experimental data are the mean \pm standard error (SD) of three independent experiments. All markers in tumor tissues and adjacent tissues were evaluated by the Wilcoxon test. Kaplan-Meier survival analysis was used to draw the survival curve. We used the Cox regression model to estimate the HRs and $95 \%$ Cls. $\mathrm{P}<0.05$ was considered statistically significant.

\section{Results}

\section{LncRNA 604 is elevated in CRC tissues and cell lines}


To study the expression of IncRNA 604 in CRC tissues and cells, fresh CRC tissues and corresponding paracancerous tissues were used for high-throughput sequencing. As shown in Fig. 1A, we found that the expression of IncRNA 604 was consistently higher in CRC tissues than in paracancerous tissues. Then, we used qRT-PCR to detect the expression of IncRNA 604 in CRC tissues and cells. The results showed that IncRNA 604 was highly expressed in CRC tissues compared with paracancerous tissues (Fig. 1B). The expression of IncRNA 604 in CRC cells (SW620, HCT116, HT29, SW480, RKO and HCT15) was significantly higher than that in FHC (Fig. 1C).

To further verify the expression of IncRNA 604 in CRC, we constructed tissue microarrays of 470 CRC patients. The pathological data of each patient in the database are detailed in Table S1. We used FISH to detect the expression of IncRNA 604 on the tissue microarrays. Fluorescent images of cancer tissues and normal tissues were selected as shown in Fig. 1D and Fig. 1E. We used Image-Pro Plus 6.0 software to calculate the specific value of each fluorescent spot in the tissue. Through the data analysis, we concluded that the expression of IncRNA 604 in CRC tissues was significantly increased compared with that in normal tissues (Fig. $1 F, P<0.001)$. Using Kaplan-Meier survival analysis, we found that the overall survival (OS) of CRC patients with low expression of IncRNA 604 was significantly prolonged compared with patients with high expression of IncRNA 604 (Fig. 1G, P<0.001).

\section{LncRNA 604 promotes CRC cell proliferation and metastasis}

To explore the function of IncRNA 604 in CRC cells, we first constructed lentiviruses to vary the expression of IncRNA 604 in CRC cells. As shown in Fig. 2A, overexpression of IncRNA 604 in HCT116 and HT29 cells was achieved using LV-LncRNA 604; LVLncRNA 604-RNAi was used to knock down IncRNA 604 in cells. Then, we performed a CCK-8 assay to detect the proliferation of CRC cells when IncRNA 604 expression was altered. We found that overexpression of IncRNA 604 in HCT116 and HT29 cells promoted cell proliferation, while decreased expression had the opposite effect (Fig. 2B, 2C; all P<0.05). We also performed an EdU assay and found that the proliferation capacity of CRC cells was elevated when IncRNA 604 was increased in HCT116 and HT29 cells, while the opposite was found when IncRNA 604 expression was decreased (Fig. 2D, 2E).

To examine the function of IncRNA 604 in metastasis, we used Transwell assays and high-content imaging system analysis in vitro. Through these data, we concluded that the invasion and migration abilities of HCT116 and HT29 cells were significantly enhanced in LV-LncRNA 604 cells but weakened in LV-LncRNA 604-RNAi cells compared with the corresponding control group (Fig. $2 \mathrm{~F}, 2 \mathrm{G}, * * \mathrm{P}<0.01)$. As shown in Fig. $2 \mathrm{H}$ and $2 \mathrm{l}$, high-content imaging system analysis showed that the metastatic abilities of LVLncRNA 604 cells were also elevated compared with those of the control group, but LV-LncRNA 604-RNAi cells showed the opposite trend.

\section{LncRNA 604 functions as a ceRNA to bind miRNA 564 and promotes tumor progression via the miRNA 564/AEG-1 signaling axis}

To study the mechanism of action of IncRNA 604, we first used a FISH assay to detect its expression and localization in the cells. The results showed that IncRNA 604 was mostly located in the cytoplasm, and only a small part was expressed in the nucleus compared with the nuclear localization marker U1 and the cytoplasmic localization marker 18S (Fig. 3A, 3B). Then, we used TargetScan software to predict the IncRNA 604 spatial signal regulation network. As shown in Fig. 3C, we found that numerous miRNAs bound to IncRNA 604, such as miRNA 564, miRNA 146b-3p, and miRNA 1976.

From these bound miRNAs, qRT-PCR was used to verify whether a regulatory relationship existed. We found that miRNA 564 was regulated by IncRNA 604 (Fig. 3D). Subsequently, we used a dual luciferin reporter assay to verify this result. As shown in Fig. 3E, we predicted the binding site of IncRNA 604 and miRNA 564 through bioinformatics analysis. The wild-type IncRNA 604 luciferase plasmid containing miRNA 564 binding sites and a mutant IncRNA 604 plasmid were generated. These plasmids were cotransfected with miRNA into HEK293T cells. We found that miRNA 564 could reduce wild-type IncRNA 604 luciferase activity, but mutant IncRNA 604 activity was not changed (Fig. 3F). The results indicated that miRNA 564 bound to the wild-type IncRNA 604.

We used MiRanda (http://www.microrna.org) to search for putative target genes of miRNA 564 (Fig. 3G). The 3'-UTR of AEG-1 was predicted to be the putative binding site of miRNA 564 because it contained a region matching the seed sequence of miRNA 564 
(Fig. 3H). Accordingly, the dual luciferin reporter assay was used for further validation. As shown in Fig. 3I, miRNA 564 mimics reduced the luciferase activity of the wt 3'UTR of AEG-1 but had no effect on the luciferase activity of the mut 3'UTR of AEG-1. Through qRT-PCR and WB assays, we confirmed that miRNA 564 could negatively regulate AEG-1 at both the RNA and protein levels (Fig. 3J, 3K). Taken together, we concluded that the IncRNA 604/miR-564/AEG-1 axis was important in CRC and that IncRNA 604 could promote tumor progression by regulating miRNA 564 and AEG-1.

\section{LncRNA 604 binds nuclear transcription factor ZNF326}

Through the results of the FISH experiment, we found that IncRNA 604 was mostly located in the cytoplasm, but a small portion existed in the nucleus. Previously, we found that IncRNA 604 could adsorb miRNA564 in the cytoplasm through a ceRNA mechanism, thereby promoting tumor metastasis. To further study whether IncRNA 604 in the nucleus plays a biological function, we used an RNA pulldown assay to pull out all bound proteins by silver staining (Fig. 4A). Subsequently, all of the proteins were identified by mass spectrometry. As shown in Fig. 4B, ZNF326 was the second most differentially expressed protein in the IncRNA 604-binding product. We also performed WB to confirm this specific binding (Fig. 4C).

ZNF326 is a nuclear transcription factor and acts as an oncoprotein in breast cancer, promoting the occurrence of EMT. We used the WB assay to detect important proteins of the EMT signaling pathway. The results showed that ZNF326, N-cad, and Vim expression was increased, and E-cad expression was decreased in the IncRNA 604 high expression group; ZNF326, N-cad, and Vim expression was decreased, and the expression of E-cad was increased in the IncRNA 604 low expression group compared with the corresponding control group (Fig. 4D).

According to the above mechanistic research results, we concluded that IncRNA 604 may not only inhibit AEG-1 by combining with miRNA564 in the cytoplasm but also regulate the nuclear transcription factor ZNF326 in the nucleus, which could promote the occurrence of EMT and lead to CRC metastasis (Fig. 4E).

\section{LncRNA 604 accelerates CRC cell growth and metastasis in vivo}

To investigate the functional role of IncRNA 604 in CRC cell proliferation in vivo, luciferase-expressing LV-IncRNA 604 or LV-IncRNA 604-RNAi HCT116 cells were implanted subcutaneously into the flanks of nude mice. At days 7, 14 and 21, we injected fluorescein potassium into the abdominal cavity of nude mice and then observed the size of tumors using a small-animal living imaging system after $15 \mathrm{~min}$. Tumor growth was dramatically increased in the LV-IncRNA 604 group but suppressed in the LV-IncRNA 604RNAi group compared with the corresponding control group (Fig. 5A). Simultaneously, we detected the expression of IncRNA 604 in xenograft tumors by FISH. The trend of IncRNA 604 expression in tissues was consistent with that in cells (Fig. 5B).

In addition, LV-IncRNA 604 or LV-IncRNA 604-RNAi HCT116 cells were injected into the peritoneal cavity of BALB/c nude mice. We observed abdominal metastases at days 7, 14 and 21. As shown in Fig. 5C, more metastases were found in the LV-IncRNA 604 group than in the control group; however, the LV-IncRNA 604-RNAi group showed the opposite result. The IncRNA 604 expression in abdominal metastases was consistent with that in cells (Fig. 5D). Furthermore, we used the tail vein metastasis model to study the role of IncRNA 604 in tumor metastasis. At day 40, we found that there were more metastases in the LV-IncRNA 604 group than in the control group, but the LV-IncRNA 604-RNAi group had significantly fewer metastases than the control group (Fig. 5E). As expected, IncRNA 604 expression in metastases was consistent with that in cells (Fig. 5F). From these results, we concluded that IncRNA 604 could promote CRC cell growth and metastasis in vivo.

\section{LncRNA 604 alone or in combination with its regulatory molecules predicts the prognosis of CRC}

To further explore the clinical value of IncRNA 604, we used Fisher's exact analysis to analyze the correlation between IncRNA 604, miRNA 564, ZNF326 and patients' clinicopathological parameters in the CRC cohort. We performed FISH assays and immunohistochemistry to detect miRNA 564 and ZNF326, respectively. The same method as IncRNA 604 was used to obtain the expressed value of miRNA 546, and the expression of ZNF326 was assessed according to our previously published paper [17].

Page $7 / 24$ 
Representative photos are shown in Fig. 6A, 6B, and 6C. As shown in Table 1, IncRNA 604 expression had a significant positive association with lymph node metastasis, TNM stage and distant metastasis (all P< 0.001); miRNA 564 expression was significantly associated with depth of invasion, lymph node metastasis, TNM stage (all $P<0.001)$ and distant metastasis $(P<$ 0.05); ZNF326 expression was significantly associated with age $(P<0.05)$, pathological classification, depth of invasion, lymph node metastasis, and TNM stage (all $P<0.001$ ). Fig. 6D shows that miRNA 564 expression was lower in tumor tissues than in nontumor tissues $(P<0.001)$. Furthermore, we found that ZNF326 expression was higher in tumor tissues than in nontumor tissues $(P<0.001$; Fig. 6E).

Table1 Relationship between expression levels of Lnc RNA 604, miRNA 564, ZNF326 and clinicopathological features in CRC patients 


\begin{tabular}{|c|c|c|c|c|c|c|c|c|c|}
\hline \multirow[t]{3}{*}{ Variables } & \multicolumn{3}{|c|}{ Lnc RNA 604} & \multicolumn{3}{|c|}{ miRNA 564} & \multicolumn{3}{|c|}{ ZNF326 } \\
\hline & \multicolumn{3}{|c|}{$\mathrm{n}=456$ cases } & \multicolumn{3}{|c|}{$\mathrm{n}=456$ cases } & \multicolumn{3}{|c|}{$\mathrm{n}=467$ cases } \\
\hline & low口\%马 & high $\square \% \square$ & $\mathrm{P}^{\mathrm{a}}$ & low口\%马 & high $\square \%]$ & $\mathrm{P}^{\mathrm{a}}$ & low $\% \square$ & high $\square \% \square$ & $\mathrm{P}^{\mathrm{a}}$ \\
\hline All patients & 323ロ70.83ロ & $133 \square 29.17 \square$ & & 277ロ60.7ロ & 179ロ39.3ロ & & $325 \square 69.6 \square$ & $142 \square 30.4 \square$ & \\
\hline Age (years) & & & 0.414 & & & 0.378 & & & 0.004 \\
\hline$\leq 65$ & $185 \square 71.4 \square$ & $74 \square 28.6 \square$ & & $154 \square 59.9 \square$ & $103 \square 40.1 \square$ & & 198ロ74.7\ & 67ロ25.3ロ & \\
\hline$\square 65$ & $138[70.10$ & $59 \square 29.9 \square$ & & $123 \square 61.8 \square$ & $76 \square 38.2 \square$ & & 127ロ62.9[ & $75 \square 37.1 \square$ & \\
\hline Gender & & & 0.085 & & & 0.120 & & & 0.528 \\
\hline Males & $199 \square 73.4 \square$ & $72 \llbracket 26.6 \square$ & & $156 \square 57.8 \square$ & $114 \llbracket 42.2 \square$ & & $195 \square 69.6 \square$ & $85 \square 30.4 \square$ & \\
\hline Females & $124 \square 67.0 \square$ & 61ロ33.0૫ & & $121 \square 65.1 \square$ & $65 \square 34.9 \square$ & & $130 \square 69.5 \square$ & 57ロ30.5ロ & \\
\hline $\begin{array}{l}\text { Pathological } \\
\text { classification }^{\text {b }}\end{array}$ & & & 0.445 & & & 0.104 & & & $<0.001$ \\
\hline प & $4 \square 80.0 \square$ & $1 \square 20.0 \square$ & & $1 \square 25.0 \square$ & $3 \square 75.0 \square$ & & $4 \square 80.0 \square$ & $1 \square 20.0 \square$ & \\
\hline प & $292 \square 71.4 \square$ & 117ロ28.6ロ & & $244 \llbracket 59.5 \square$ & $166 \square 40.5 \square$ & & 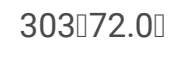 & $118 \square 28.0 \square$ & \\
\hline प & $22 \square 47.8 \square$ & $24(52.2 \square$ & & $26 \square 72.2 \square$ & $10(27.8[$ & & $14 \square 38.9 \square$ & 22 & \\
\hline & & & & & & & & $(61.10$ & \\
\hline $\begin{array}{l}\text { Depth of } \\
\text { invasion }^{b}\end{array}$ & & & 0.076 & & & $<0.001$ & & & $<0.001$ \\
\hline $\mathrm{T} 1+\mathrm{T} 2$ & $76 \square 76.8 \square$ & $23 \square 23.2 \square$ & & $43 \square 43.9 \square$ & $55 \square 56.1 \square$ & & 93ロ84.3ロ & 9ロ15.7\ & \\
\hline $\mathrm{T} 3+\mathrm{T} 4$ & $242 \square 68.8 \square$ & $110 \square 31.2)$ & & $230 \square 65.2 \square$ & 123ロ34.8) & & $228 \square 56.0 \square$ & 133凸44.0) & \\
\hline $\begin{array}{l}\text { Lymph node } \\
\text { metastasis }^{b}\end{array}$ & & & $<0.001$ & & & $<0.001$ & & & $<0.001$ \\
\hline No & $214 \square 80.5 \square$ & $52 \square 19.5 \square$ & & 118ロ44.7\ & $146 \square 55.3 \square$ & & 216ロ78.8ロ & $58 \square 21.2 \square$ & \\
\hline $\mathrm{N} 1+\mathrm{N} 2+\mathrm{N} 3$ & $105 \square 56.5 \square$ & $81 \square 43.5 \square$ & & $156 \square 83.0 \square$ & $32 \square 17.0 \square$ & & $106 \square 55.8 \square$ & $84 \square 44.2 \square$ & \\
\hline TNM stage $^{\mathrm{b}}$ & & & $<0.001$ & & & $<0.001$ & & & $<0.001$ \\
\hline प & $66 \square 78.6 \square$ & $18 \square 21.4 \square$ & & $34 \square 40.5 \square$ & $50 \square 59.5 \square$ & & $80 \square 92.0 \square$ & 7 & \\
\hline & & & & & & & & ๑8.0૫ & \\
\hline प & 143ロ82.7ロ & $30 \square 17.3 \square$ & & $78 \square 45.6 \square$ & $93 \square 54.4 \square$ & & 134ロ75.3ロ & $44 \square 24.7 \square$ & \\
\hline प & $73 \square 50.0 \square$ & $73 \square 50.0 \square$ & & $\begin{array}{c}147 \\
\square 82.6 \square\end{array}$ & 31口17.4【 & & $101 \square 56.1 \square$ & $79 \square 43.9 \square$ & \\
\hline प & $12 \square 50.0 \square$ & $12 \square 50.0 \square$ & & $14 \square 82.4 \square$ & $3 \square 17.6 \square$ & & $5 \square 29.4 \square$ & $12 \square 70.6 \square$ & \\
\hline $\begin{array}{l}\text { Tumor } \\
\text { diameter }^{b}\end{array}$ & & & 0.093 & & & 0.530 & & & 0.114 \\
\hline$\leq 5 \mathrm{~cm}$ & $266 \square 72.3 \square$ & 102ロ27.7\ & & $222 \square 60.8 \square$ & $143 \square 39.2 \square$ & & 266ロ70.9ロ & $109 \square 29.1 \square$ & \\
\hline$\square 5 \mathrm{~cm}$ & $56 \square 64.4 \square$ & $31 \square 35.6 \square$ & & $55 \square 61.1 \square$ & $35 \square 38.9 \square$ & & $58 \square 65.9 \square$ & $33 \sqcap 34.1 \square$ & \\
\hline $\begin{array}{l}\text { Distant } \\
\text { metastasis }\end{array}$ & & & $<0.001$ & & & 0.024 & & & $<0.001$ \\
\hline MO & $318(72.8)$ & $119(27.2)$ & & $\begin{array}{c}261 \\
(59.7)\end{array}$ & $\begin{array}{c}176 \\
(40.3)\end{array}$ & & 320 & 128 & \\
\hline & & & & & & & (71.4) & $(28.6)$ & \\
\hline & & & & Page $9 / 24$ & & & & & \\
\hline
\end{tabular}




M1 $5 \quad(26.3) \quad 14(73.7)$

16

(84.2)

$3(15.8)$

5

(26.3)

a Two-sided Fisher's exact tests

b Some patients missing these clinical pathological parameters

The cutoff values of IncRNA 604 and miRNA 564 were calculated by Cutoff Finder (http://molpath.charite.de/cutoff/index.jsp). We used receiver operator characteristic (ROC) analysis to obtain the cutoff value of the semiquantitative immunoreactivity score (IRS) for ZNF326, as reported elsewhere [19]. Fig. 6F indicates that IRS 0-4 and IRS 6-12 were classified as low or high expression of ZNF326, respectively. Through Kaplan-Meier survival analysis, we found that CRC patients with high miRNA 564 or low ZNF326 expression had a better OS (all P < 0.001; Fig. $6 \mathrm{G}$ and 6H). As shown in Table 2 and Table 3, IncRNA 604, miRNA 564 or ZNF326 was an independent marker for the prognosis of CRC patients by univariate and multivariate Cox regression analysis.

Table2 Univariate Cox regression analysis of Lnc RNA 604, miRNA 564, ZNF326 expression and clinicopathological variables predicting survival in CRC patients

\begin{tabular}{lcc}
\multicolumn{1}{c}{ Variables } & \multicolumn{2}{c}{$\mathrm{n}=470$ cases } \\
\cline { 2 - 3 } & $\mathrm{HR}(95 \% \mathrm{Cl})$ & $\mathrm{P}$ \\
\hline Age $(\leq 65$ vs. $>$ 65) & $1.607 \square 1.215-2.126 \square$ & 0.001 \\
\hline Gender (male vs. female) & $1.013 \square 0.762-1.347 \square$ & 0.927 \\
\hline Pathological classification (I/II vs. III) & $2.475 \square 1.587-3.860 \square$ & $\square 0.001$ \\
\hline Depth of invasion (T1/T2 vs. T3/T4) & $3.687 \square 2.270-5.990 \square$ & $\square 0.001$ \\
\hline Lymph node metastasis (N0 vs. N1/N2) & $2.807 \square 2.112-3.731 \square$ & $\square 0.001$ \\
\hline TNM stage (I/II vs. III/IV) & $3.214 \square 2.407-4.291)$ & $\square 0.001$ \\
\hline Distant metastasis(M0 vs. M1) & $8.150 \square 4.849-13.699 \square$ & $\square 0.001$ \\
\hline Tumor diameter ( $\leq 5$ cm vs. >5 cm) & $1.196 \square 0.848-1.688 \square$ & 0.307 \\
\hline Lnc RNA 604 expression & $0.279 \square 0.209-0.372 \square$ & $\square 0.001$ \\
\hline (low vs. high) & & \\
\hline miRNA 564 expression & $0.289 \square 0.204-0.411 \square$ & $\square 0.001$ \\
\hline (low vs. high) & & \\
\hline ZNF326 expression & $0.075 \square 0.055-0.103 \square$ & $\square 0.001$ \\
\hline (low vs. high) & & \\
\hline
\end{tabular}

Table3 Multivariate Cox regression analysis of Lnc RNA 604, miRNA564, ZNF326, Lnc RNA 604/miRNA564, Lnc RNA 604/ZNF 326 expression and clinicopathological variables predicting survival in patients with CRC 


\section{Lnc RNA 604}

Age ( $\leq 65$ vs. $>65)$

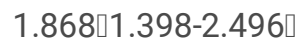

$\square 0.001$

Gender (male vs. female)

0.797ロ0.593-1.071ם

0.132

Pathological classification (I/II vs. III)

2.133凸1.318-3.451口 $\quad 0.002$

TNM stage (I/II vs. III/IV)

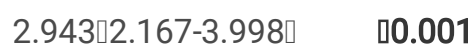

Tumor diameter ( $\leq 5 \mathrm{~cm}$ vs. $>5 \mathrm{~cm}$ )

$1.065 \square 0.731-1.552 \square \quad \mathbf{0 . 7 4 3}$

Lnc RNA 604 expression (low vs. high)

0.372 $0.250-0.554 \square \quad \square 0.001$

miRNA564

Age ( $\leq 65$ vs. $>65)$

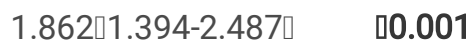

Gender (male vs. female)

0.833ロ0.623-1.116ロ $\quad 0.221$

Pathological classification (I/II vs. III)

2.0631.291-3.296! $\quad 0.002$

TNM stage (I/II vs. III/IV)

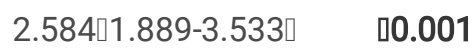

Tumor diameter $(\leq 5 \mathrm{~cm}$ vs. $>5 \mathrm{~cm}$ )

$1.057 \square 0.733-1.525 \square \quad 0.767$

miRNA564 expression (low vs. high)

$0.396 \square 0.274-0.571 \square \quad \square 0.001$

\section{ZNF326}

Age ( $\leq 65$ vs. $>65)$

1.495ロ1.116-2.003ロ $\quad 0.007$

Gender (male vs. female)

$0.969 \square 0.727-1.292 \square \quad 0.834$

Pathological classification (I/II vs. III)

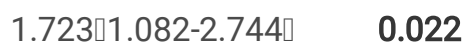

TNM stage (I/II vs. III/IV)

2.198ロ1.625-2.972 $\quad \square 0.001$

Tumor diameter $(\leq 5 \mathrm{~cm}$ vs. $>5 \mathrm{~cm}$ )

1.118ロ0.778-1.606ロ $\mathbf{0 . 5 4 8}$

ZNF 326 expression (low vs. high)

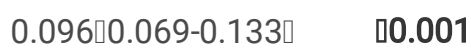

\section{Lnc RNA 604/miRNA564}

Age ( $\leq 65$ vs. $>65)$

$1.858[1.386-2.489[$

00.001

Gender (male vs. female)

0.868ロ0.647-1.163ロ $\mathbf{0 . 6 3 4}$

Pathological classification (I/II vs. III)

2.116ロ1.317-3.398[ $\quad 0.002$

TNM stage (I/II vs. III/IV)

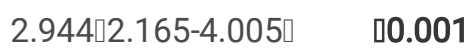

Tumor diameter $(\leq 5 \mathrm{~cm}$ vs. $>5 \mathrm{~cm}$ )

$1.039 \square 0.714-1.512 \square$

0.840

Lnc RNA 604/miRNA564 expression

Lnc RNA 604 low and miRNA564 high vs. both low or high

0.499(0.354-0.705)

$\square 0.001$

Lnc RNA 604 low and miRNA564 high vs. Lnc RNA 604 high and miRNA564 low

0.271(0.167-0.438) 00.001

\section{Lnc RNA 604/ZNF326}

Age ( $\leq 65$ vs. $>65)$

1.904ロ1.432-2.530ם

$[0.001$

Gender (male vs. female)

0.902־0.677-1.203ロ

0.483

Pathological classification (I/II vs. III) 1.9581.232-3.111口 $\quad 0.004$

TNM stage (I/II vs. III/IV)

3.357ロ2.500-4.508ロ 00.001 


\begin{tabular}{|c|c|c|}
\hline Tumor diameter $(\leq 5 \mathrm{~cm}$ vs. $>5 \mathrm{~cm})$ & $1.155 \square 0.807-1.652 \square$ & 0.430 \\
\hline \multicolumn{3}{|l|}{ Lnc RNA 604/ZNF326 expression } \\
\hline Both low vs. both high & $0.038 \square 0.023-0.062 \square$ & $\square 0.001$ \\
\hline Both low vs.one high and one low & $5.215 \square 3.563-7.632 \square$ & $\square 0.001$ \\
\hline
\end{tabular}

${ }^{a}$ Multivariate Cox regression analysis including gender, pathological classification, TNMstage, tumor diameter, Lnc RNA 604, miRNA564, ZNF326, Lnc RNA 604/miRNA564, Lnc RNA 604/ZNF326 expression status.

According to the above mechanistic research, we concluded that IncRNA 604 promoted CRC cell growth and metastasis through miRNA 564 or ZNF326. These three indicators were all effective molecular markers for predicting the prognosis of CRC patients. We hypothesized whether IncRNA 604 could be combined with other markers to better predict the prognosis of CRC patients. We used the Kaplan-Meier survival analysis method again to investigate this hypothesis. The results showed that patients with low expression of IncRNA 604 and high expression of miRNA 564 had the best survival prognosis compared with both the high/low expression group or the IncRNA 604 high and miRNA 564 low expression group $(P<0.001$; Fig. $6 \mathrm{I})$. As shown in Fig. $6 \mathrm{~J}$, we also noted that patients with low expression of IncRNA 604 and ZNF326 had a more favorable survival outcome than both the high expression group and the high and low expression groups $(P<0.001)$. Simultaneously, multivariate Cox regression analysis indicated that low expression of IncRNA 604 and high expression of miRNA 564 and low expression of IncRNA 604 and ZNF326 were favorable independent prognostic factors (all $P<0.001$, Table 3 ). In addition, we conducted a time-dependent ROC analysis to further evaluate whether IncRNA 604 combined with miRNA 564 or ZNF326 had a synergistic effect on the prognosis of CRC patients. The clinical risk scores (TNM stage, histologic type, and tumor diameter), IncRNA 604 or miRNA 564 or IncRNA 604 plus miRNA 564 combined with the clinical risk scores are shown in Fig. 6K. Our data indicated that IncRNA 604 plus miRNA 564 combined with the clinical risk scores contributed more than any one of these markers alone. As shown in Fig. $6 \mathrm{~L}$, our data also indicated that IncRNA 604 plus ZNF326 combined with the clinical risk scores had the best predictive effect on the prognosis of CRC compared with the other three groups.

\section{LncRNA 604 promotes CRC cell chemoresistance}

We analyzed the database using the Kaplan-Meier curve method and found that patients with low IncRNA 604 expression had a significantly longer survival time from the postoperative LFP regimen (5-Fu+L-OHP) than patients who received surgery alone $(\mathrm{P}<$ 0.05, Fig. 7A), while patients with high IncRNA 604 expression did not benefit ( $P>0.05$, Fig. 7B). To further investigate this finding, we performed a CCK-8 assay to detect cell proliferation when LV-IncRNA 604 or LV-IncRNA 604-RNAi CRC cells were in the presence of $20 \mu \mathrm{g} / \mathrm{ml} \mathrm{5-Fu} \mathrm{and} 20 \mu \mathrm{g} / \mathrm{ml}$ L-OHP. Our data indicated that LV-IncRNA 604-RNAi CRC cells were more sensitive than the control group; however, LV-IncRNA 604 cells were not sensitive (Fig. 7C: HCT116; Fig. 7D: HT29).

To explore the corresponding mechanism, we used RT-PCR and WB to detect drug resistance proteins. We found that AEG-1, NF-KB, and ERCC1 in HCT116 cells changed with the expression of IncRNA 604 regardless of RNA (Fig. 7E) or protein levels (Fig. 7F, 7G). As shown in Fig. 7H, 7I and 7J, the test result of HT29 was consistent with HCT116. Then, we performed animal experiments to verify this finding in vivo. The model of subcutaneous metastasis was the same as described previously. After 14 days, $25 \mathrm{mg} / \mathrm{kg}$ 5 -Fu and $5 \mathrm{mg} / \mathrm{kg} \mathrm{L-OHP}$ were injected into the abdominal cavity once a week three times. After one cycle of chemotherapy, the subcutaneous tumor was observed using a small-animal living imaging system. All the nude mice were sacrificed. These data showed that the tumors were significantly smaller in the low-expression IncRNA 604 group, while the high-expression IncRNA 604 group failed to benefit compared with their respective control groups (Fig. 8A). We calculated the tumor inhibition rate according to the formula $=(1$-experimental group tumor weight/control group tumor weight $) * 100 \%$. The tumor inhibition rate of each group is shown in Table 4. The results showed that the tumor inhibition rate of the low-expression IncRNA 604 group after chemotherapy was significantly different from that of the control group, but there was no difference in the high-expression group. Subsequently, the protein expression of AEG-1, NF-KB, and ERCC1 in subcutaneous tumors was detected using IHC. The results indicated that the expression levels of AEG-1, NF-KB, and ERCC1 were higher in the high-expression IncRNA 604 group than in the low-expression IncRNA 604 group (Fig. 8B, 8C, 8D). As shown in Fig. 8E, the IRS staining scores of all groups were determined. Based on these 
experimental results, we concluded that IncRNA 604 may increase the drug resistance of CRC cells by enhancing the expression of AEG-1, NF-KB, and ERCC1.

Table 4

Effects of chemotherapeutic drugs on subcutaneous tumor constructed by CRC cell lines of high-expressed or low-expressed IncRNA 604 and respective control cell $(\nabla X \pm S, n=3)$

\begin{tabular}{|lll|}
\hline Group & Tumor weight(g) & Tumor inhibition rate(\%) \\
\hline LV-LncRNA 604 & $1.731 \pm 0.222$ & \\
\hline LV-LncRNA 604+Chemotherapy & $0.588 \pm 0.103$ & $66.0 \%$ \\
\hline LV-LncRNA 604-ctrl & $1.097 \pm 0.074$ & \\
\hline LV-LncRNA 604-ctrl+Chemotherapy & $0.365 \pm 0.021$ & $66.7 \% \triangle$ \\
\hline LV-LncRNA 604-RNAi & $0.747 \pm 0.120$ & \\
\hline LV-LncRNA 604-RNAi+Chemotherapy & $0.191 \pm 0.046$ & $74.4 \%$ \\
\hline LV-LncRNA 604-RNAi-ctrl & $0.945 \pm 0.121$ & \\
\hline LV-LncRNA 604-RNAi-ctrl+Chemotherapy & $0.337 \pm 0.125$ & $64.4 \%{ }^{*}$ \\
\hline Note: Compared with the respective control group, ${ }^{*} P<0.05, \triangle P>0.05$ \\
\hline
\end{tabular}

\section{Discussion}

In recent years, IncRNAs have been shown to play an important role in the occurrence and development of many cancers [20, 21], including CRC $[22,23]$. In this article, we performed high-throughput sequencing on 3 cases of fresh CRC and corresponding adjacent tissues. The results showed that IncRNA 604 was highly expressed in CRC tissues. Then, we verified this conclusion again in cell, tissue and sample databases. However, whether IncRNA 604 has a biological function and the related mechanism of action had not been studied.

In our study, we attempted to identify the function and mechanism of IncRNA 604 in CRC. Through in vivo and in vitro experiments, our data indicated that IncRNA 604 promoted the proliferation and metastasis of CRC cells. To elucidate the possible mechanism of IncRNA 604, we used a FISH assay to show that IncRNA 604 was mostly located in the cytoplasm and that only a small portion was located in the nucleus. The common mechanism of IncRNAs, such as IncRNAs in the cytoplasm, has a ceRNA mode that binds miRNAs; IncRNAs in the nucleus can bind nuclear transcription factors. Considering these two mechanisms of action, we attempted to identify which mechanism is used by IncRNA 604. Research results showed that miRNA 564 could be directly combined with IncRNA 604. Many studies have shown that miRNA 564 has antitumor effects in cancer [24-26]. In addition, we found that miRNA 564 had antitumor effects through negative regulation of AEG-1. Studies have confirmed that AEG-1 could promote the occurrence of EMT [27, 28]. Therefore, we concluded that IncRNA 604 may promote EMT through the miRNA 564/AEG-1 signaling axis in the cytoplasm, which leads to CRC metastasis. We also used an RNA pulldown experiment to pull down all of the proteins that bind to IncRNA 604 and then performed mass spectrometry analysis. We found that IncRNA 604 binds to the nuclear transcription factor ZNF326 and could positively regulate its expression. Furthermore, we demonstrated that ZNF326 could accelerate the occurrence of EMT $[29,30]$. Therefore, we also concluded that IncRNA 604 could promote the metastasis of CRC by regulating ZNF326 in the nucleus.

Previous studies have shown that IncRNAs have been increasingly reported to be related to the prognosis of cancer patients [3133]. In the pathogenesis of CRC, an increasing number of IncRNAs that have important clinical value have been identified. LncRNAs, such as ZFAS1, SNHG11, LINC00909 and LINC00654, could be used as effective markers for predicting prognosis and early diagnosis of CRC [34, 35]. In this study, IncRNA 604 expression was significantly higher in CRC tissues than in normal adjacent tissues. Simultaneously, we used the Kaplan-Meier survival method and Cox regression to analyze the relationship of IncRNA 604 and its regulatory molecules with the prognosis of CRC. Our data indicated that IncRNA 604, miRNA 564 and ZNF326 
were all independent predictors of the prognosis of CRC. Notably, IncRNA 604 combined with miRNA 564 or ZNF326 had a synergistic effect, which was better than the prediction effect of any single molecule.

Chemotherapy drug resistance is the main reason for the failure of CRC treatment [36]. Many IncRNAs are related to the sensitivity to chemotherapy drugs $[36,37]$. LncRNA CRNDE regulates the Wnt/ $\beta$-catenin signaling pathway through miR-181a-5p, promoting the proliferation of CRC cells and increasing the tolerance to chemotherapy drugs [38]. In the present article, we first found that low expression of IncRNA 604 in CRC patients with LFP after postoperative chemotherapy could significantly prolong OS, while high expression of IncRNA 604 in CRC patients did not benefit. Then, we verified this conclusion by drug sensitivity experiments in vitro. CRC cells expressing low levels of IncRNA 604 were more sensitive to chemotherapy drugs than control cells. Our data showed that IncRNA 604 could increase the expression of AEG-1, NF-KB, and ERCC1, resulting in drug resistance in CRC cells.

\section{Conclusions}

In our investigation, we studied the function, mechanism and clinical value of IncRNA 604 in CRC. We have demonstrated that the IncRNA 604/miRNA 564/AEG-1/EMT or IncRNA 604/ZNF326/EMT signaling axis may play an important role in CRC progression. LncRNA 604 is an independent and effective molecule for predicting the prognosis of CRC. We also established that IncRNA 604 could increase drug resistance protein expression, resulting in chemoresistance in CRC cells. Our study may provide new insights for CRC treatments.

\section{Abbreviations}

CRC: Colorectal cancer; IncRNAs: long-chain noncoding RNAs; IncRNA 604: IncRNA-ENST00000543604; LV: lentivirus; RNAi: RNA interference; TMA: Tissue Microarray; IRS: immunoreactivity score; CCK-8: Cell Counting Kit-8; FISH: Fluorescence in situ hybridization; qRT-PCR: Quantitative real-time PCR; 5-FU: 5-fluorouracil; ceRNA: Competing endogenous RNAs; OS: overall survival; EMT: Epithelial-Mesenchymal Transition.

\section{Declarations}

\section{Acknowledgements}

We would like to thank AJE (https://www.age.com) for English language editing.

\section{Authors' contributions}

WMW and ZZ contributed to the conception and design of the study. WMW, XJD and HBW contributed to the conception, design and editing of the manuscript. JJ and KM contributed to the statistical analysis. ZZ, YFW and MYL contributed to complete experiments. YQL and YZ critically reviewed the manuscript. All authors read and approved the final version of the manuscript.

\section{Funding}

The work was financially supported by Top Talent Support Program for young and middle-aged people of Wuxi Health Committee (awarded to WMW); Wuxi City Health Planning Commission project (No. Z201907, awarded to YZ); the Natural Science Foundation of Jiangsu Province (No. BK20191149, awarded to YZ); the National Natural Science Foundation of China (No. 82104946, awarded to HBW).

\section{Ethics approval and consent to participate}

The procedures of this study were approved by the Ethics Committee of Yixing Hospital and were performed according to the principles of the Declaration of Helsinki. Animal studies were performed in accordance with the National Institutes of Health Guide for the Care and Use of Laboratory Animals. All animal experiments were conducted in accordance with the Committee of YangZhou University for the Use and Care of Animals.

\section{Competing interests}

Page $14 / 24$ 
The authors report no conflicts of interest for this work.

\section{Consent for publication}

All authors agree with the content of the manuscript

\section{Availability of data and materials}

The datasets in our article are available from the corresponding author on reasonable request.

\section{References}

1. Xu K, Han B, Bai Y, Ma XY, Ji ZN, Xiong Y, Miao SK, Zhang YY, Zhou LM. MiR-451a suppressing BAP31 can inhibit proliferation and increase apoptosis through inducing ER stress in colorectal cancer. Cell Death Dis. 2019;10(3):152.

2. Huebner M, Hübner M, Cima RR, Larson DW. Timing of complications and length of stay after rectal cancer surgery. J Am Coll Surg. 2014;218(5):914-9.

3. Weichand B, Popp R, Dziumbla S, Mora J, Strack E, Elwakeel E, 0000-0002-0219-9653 AO, Frank AC, Scholich K, Pierre S, Syed $\mathrm{SN}, 0000-0002-6660-6561 \mathrm{AO}$, et al. S1PR1 on tumor-associated macrophages promotes lymphangiogenesis and metastasis via NLRP3/IL-1ß. J Exp Med 2017;214(9):2695-713.

4. Araghi M, 0000-0003-3896-6401 AO, Soerjomataram I, Jenkins M, Brierley J, Morris E, 0000-0002-1075-6544 AO, Bray F, 00000002-3248-7787 AO, Arnold M, 0000-0003-1700-6831 AO. Global trends in colorectal cancer mortality: projections to the year 2035. Int J Cancer 2019;144(12):2992-3000.

5. Chen Y, Zhou J. 0000-0002-7571-9314 AO. LncRNAs: macromolecules with big roles in neurobiology and neurological diseases. Metab Brain Dis. 2017;32(2):281-91.

6. Ji D, Zhong X, Jiang X, Leng K, Xu Y, Li Z, Huang L, Li J, Cui Y. The role of long non-coding RNA AFAP1-AS1 in human malignant tumors. Pathol Res Pract. 2018;214(10):1524-31.

7. Chu F, Xue L, Miao H. Long noncoding RNA TP73-AS1 in human cancers. Clin Chim Acta. 2020;500:104-8.

8. Zhang X, Wang W, 0000-0002-5705-8591 AO, Zhu W, Dong J, Cheng Y, Yin Z, Shen F, 0000-0003-1977-8712 AO. Mechanisms and Functions of Long Non-Coding RNAs at Multiple Regulatory Levels. Int J Mol Sci 2019;20(22).

9. Gill JK, Maffioletti A, García-Molinero V, Stutz F, Soudet J. Fine Chromatin-Driven Mechanism of Transcription Interference by Antisense Noncoding Transcription. Cell Rep. 2020;31(5):107612.

10. Zeng Y, Ren K, Zhu X, Zheng Z, Yi G. Long Noncoding RNAs: Advances in Lipid Metabolism. Adv Clin Chem. 2018;87:1-36.

11. Tam C, Wong JH, SKW T, Zuo T, Chan TF, Ng TB. 0000-0001-7951-8838 AO. LncRNAs with miRNAs in regulation of gastric, liver, and colorectal cancers: updates in recent years. Appl Microbiol Biotechnol. 2019;103(12):4649-77.

12. Gao Z, Zhou H, Wang Y, Chen J, Ou Y. 0000-0002-6483-2661 AO. Regulatory effects of IncRNA ATB targeting miR-200c on proliferation and apoptosis of colorectal cancer cells. J Cell Biochem. 2020;121(1):332-43.

13. Wang Y, Lu Z, Wang N, Feng J, Zhang J, Luan L, Zhao W, Zeng X. 0000-0003-0593-4147 AO. Long noncoding RNA DANCR promotes colorectal cancer proliferation and metastasis via miR-577 sponging. Exp Mol Med. 2018;50(5):1-17.

14. Shao Q, Xu J, Deng R, Wei W, Zhou B, Yue C, Zhu M, Huang X, Zhu H. Long non-coding RNA-422 acts as a tumor suppressor in colorectal cancer. Biochem Biophys Res Commun. 2018;495(1):539-45.

15. Lin J, Tan X, Qiu L, Huang L, Zhou Y, Pan Z, Liu R, Chen S, Geng R, Wu J, Huang W. Long Noncoding RNA BC032913 as a Novel Therapeutic Target for Colorectal Cancer that Suppresses Metastasis by Upregulating TIMP3. Mol Ther Nucleic Acids. 2017;8:469-81.

16. Wang W, Zhou Z, Xiang L, Lv M, Ni T, Deng J, Wang H, Masatara S, Zhou Y, Liu Y. CHIP-mediated ubiquitination of Galectin-1 predicts colorectal cancer prognosis. Int J Biol Sci. 2020;16(4):719-29.

17. Wang W, Li D, Xiang L, Lv M, Tao L, Ni T, Deng J, Gu X, Masatara S, Liu Y, Zhou Y. 0000-0002-3584-7493 AO. TIMP-2 inhibits metastasis and predicts prognosis of colorectal cancer via regulating MMP-9. Cell Adh Migr. 2019;13(1):273-84. 
18. Swets M, Wouters A, Krijgsman D, van Vlierberghe RLP, Boot A, van Eendenburg JD, van Wezel T, Gelderblom H, van de Velde CJH, van den Elsen PJ, PJK K. HLA-G protein expression in colorectal cancer evaluated by immunohistochemistry and western blot analysis: Its expression characteristics remain enigmatic. Clin Immunol. 2018;194:80-6.

19. Wang W, Wang H, Xiang L, Ni T, Jin F, Deng J, Zhang Y, Shintaro I, Zhou Y, Liu Y. DJ-1 is a new prognostic marker and predicts chemotherapy efficacy in colorectal cancer. Oncol Rep. 2020;44(1):77-90.

20. Guo Y, Lv B, Liu R, Dai Z, Zhang F, Liang Y, Yu B, Zeng D, Lv XB, Zhang Z. 0000-0002-0000-3063 AO. Role of LncRNAs in regulating cancer amino acid metabolism. Cancer Cell Int. 2021;21(1):209.

21. Zhang J, Ding T, Zhang H. Insight Into Chromatin-Enriched RNA: A Key Chromatin Regulator in Tumors. Front Cell Dev Biol. 2021;9:649605.

22. Feng Y, Wu M, Hu S, Peng X, Chen F. LncRNA DDX11-AS1: a novel oncogene in human cancer. Hum Cell. 2020;33(4):946-53.

23. Li M, Bian Z, Jin G, Zhang J, Yao S, Feng Y, Wang X, Yin Y, Fei B, You Q, Huang Z. 0000-0002-0117-9976 AO. LncRNA-SNHG15 enhances cell proliferation in colorectal cancer by inhibiting miR-338-3p. Cancer Med. 2019;8(5):2404-13.

24. Meng FJ, Meng FM, Wu HX, Cao XF. miR-564 inhibited metastasis and proliferation of prostate cancer by targeting MLLT3. Eur Rev Med Pharmacol Sci. 2017;21(21):4828-34.

25. Song Z, Yang H, Wu X, Kong C, Xu C. microRNA-564 inhibits the aggressive phenotypes of papillary thyroid cancer by directly targeting astrocyte-elevated gene-1. Onco Targets Ther. 2019;12:4869-81.

26. Guo Y, Qi Y, Guo A, Du C, Zhang R, Chu X. miR-564 is downregulated in gastric carcinoma and targets E2F3. Oncol Lett. 2017;13(6):4155-60.

27. Feng S, Yao J, Zhang Z, Zhang Y, Zhang Z, Liu J, Tan W, Sun C, Chen L, Yu X. miR-96 inhibits EMT by targeting AEG-1 in glioblastoma cancer cells. Mol Med Rep. 2018;17(2):2964-72.

28. Chen $Y$, Wang X. Mechanisms of AEG-1 and CXCR4 gene expression regulating the epithelial-mesenchymal transition pathway involved in brain metastases of breast cancer. J BUON. 2017;22(4):953-7.

29. Yu X, 0000-0002-4268-5672 AO, Wang M, Han Q, Zhang X, Mao X, Wang X, Li X, Ma W, Jin F, 0000-0002-0325-5362 AO. ZNF326 promotes a malignant phenotype of breast cancer by interacting with DBC1. Mol Carcinog 2018;57(12):1803-15.

30. Rangel R, Guzman-Rojas L, Kodama T, Kodama M, Newberg JY, Copeland NG, Jenkins NA. Identification of new tumor suppressor genes in triple-negative breast cancer. Cancer Res 2017.

31. Tian X, Zhu X, Yan T, Yu C, Shen C, Hong J, Chen H, Fang JY. Differentially Expressed IncRNAs in Gastric Cancer Patients: A Potential Biomarker for Gastric Cancer Prognosis. J Cancer. 2017;8(13):2575-86.

32. Li Z, Lin W, Zheng J, Hong W, Zou J, Zhang T, Chen Y, Lu H. Identification of immune-related IncRNAs to improve the prognosis prediction for patients with papillary thyroid cancer. Biosci Rep 2021;41(2).

33. Zhang G, 0000-0002-4661-8864 AO, Fan E, Zhong Q, Feng G, Shuai Y, Wu M, Chen Q, Gou X. Identification and potential mechanisms of a 4-IncRNA signature that predicts prognosis in patients with laryngeal cancer. Hum Genomics 2019;13(1):36.

34. Wang W, Xing C. Upregulation of long noncoding RNA ZFAS1 predicts poor prognosis and prompts invasion and metastasis in colorectal cancer. Pathol Res Pract. 2016;212(8):690-5.

35. Xu W, 0000-0002-8252-1496 AO, Zhou G, Wang H, Liu Y, Chen B, Chen W, Lin C, Wu S, Gong A, Xu M. Circulating IncRNA SNHG11 as a novel biomarker for early diagnosis and prognosis of colorectal cancer. Int J Cancer 2020;146(10):2901-12.

36. Liang G, Zhu Y, Ali DJ, Tian T, Xu H, Si K, Sun B, Chen B, Xiao Z. Engineered exosomes for targeted co-delivery of miR-21 inhibitor and chemotherapeutics to reverse drug resistance in colon cancer. J Nanobiotechnology. 2020;18(1):10.

37. Chi Y, Wang D, Wang J, Yu W, Yang J. Long Non-Coding RNA in the Pathogenesis of Cancers. Cells 2019;8(9).

38. Han P, Li JW, Zhang BM, Lv JC, Li YM, Gu XY, Yu ZW, Jia YH, Bai XF, Li L, Liu YL, Cui BB. The IncRNA CRNDE promotes colorectal cancer cell proliferation and chemoresistance via miR-181a-5p-mediated regulation of Wnt/ $\beta$-catenin signaling. Mol Cancer. 2017;16(1):9.

\section{Figures}




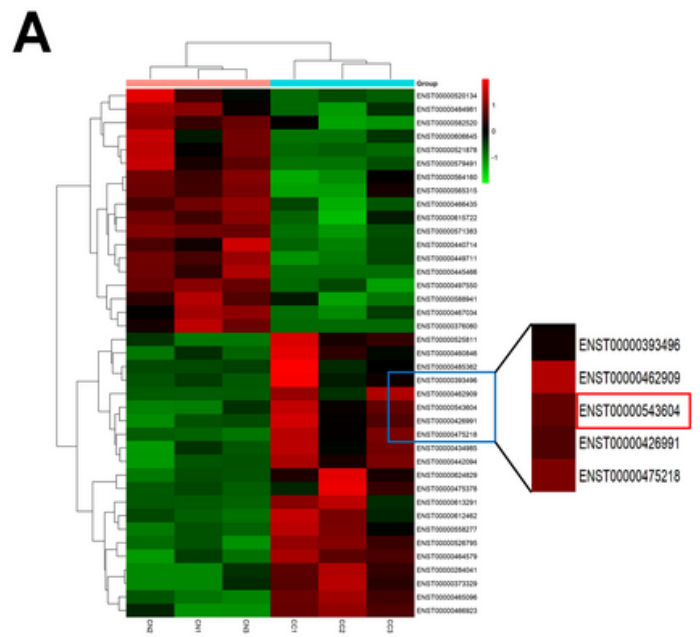

Note: CN-Normal adjacent tissue, CC-Cancer tissue

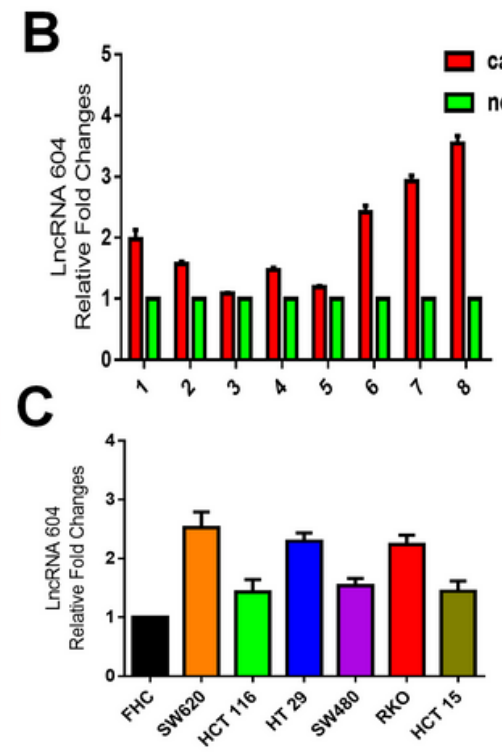

$\mathbf{F}$

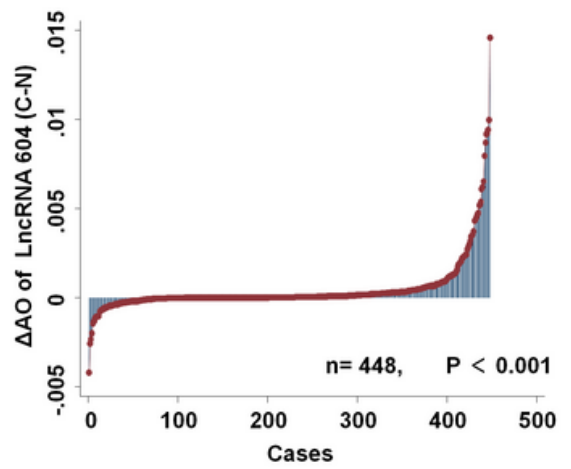

D

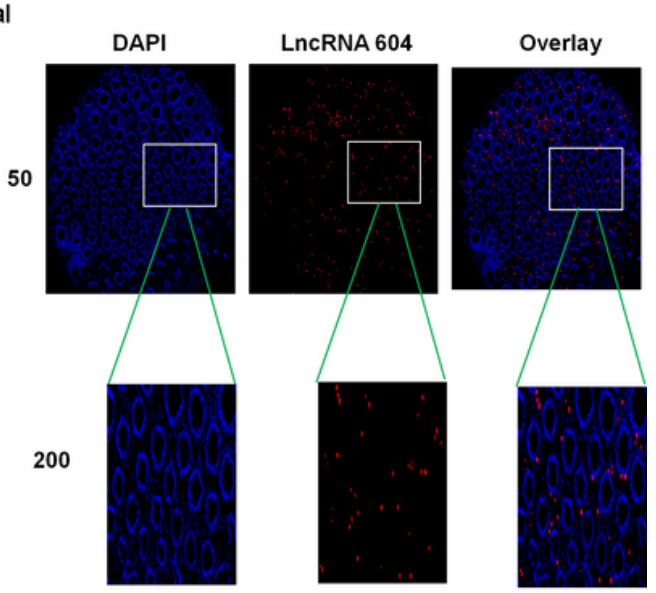

G

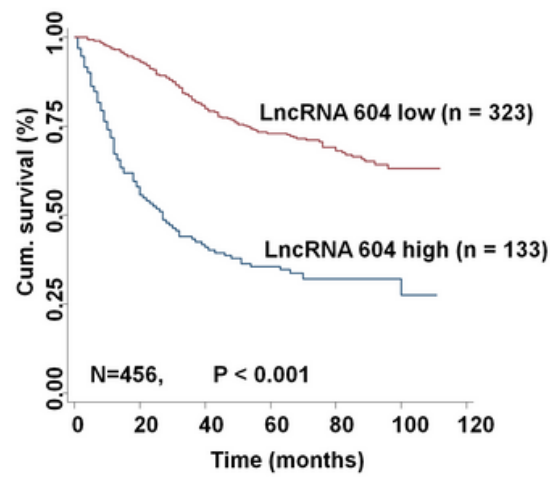

Figure 1

LncRNA 604 was consistently high in CRC tissues and cells. A: LncRNA 604 was consistently higher in CRC tissues than in paracancerous tissues by high-throughput sequencing. B: LncRNA 604 was high-expressed in CRC tissues compared with no-tumor tissues by qRT-PCR. C: LncRNA 604 in CRC cells was significantly higher than that in FHC. D, E: LncRNA 604 on the tissue microarrays was detected by FISH (D: normal tissues; E: cancer tissues). F: LncRNA 604 in CRC tissues were significantly increased compared with normal tissues on the tissue microarrays. G: The OS of CRC patients with low-expressed IncRNA 604 was significantly prolonged than patients with high-expressed IncRNA 604. 

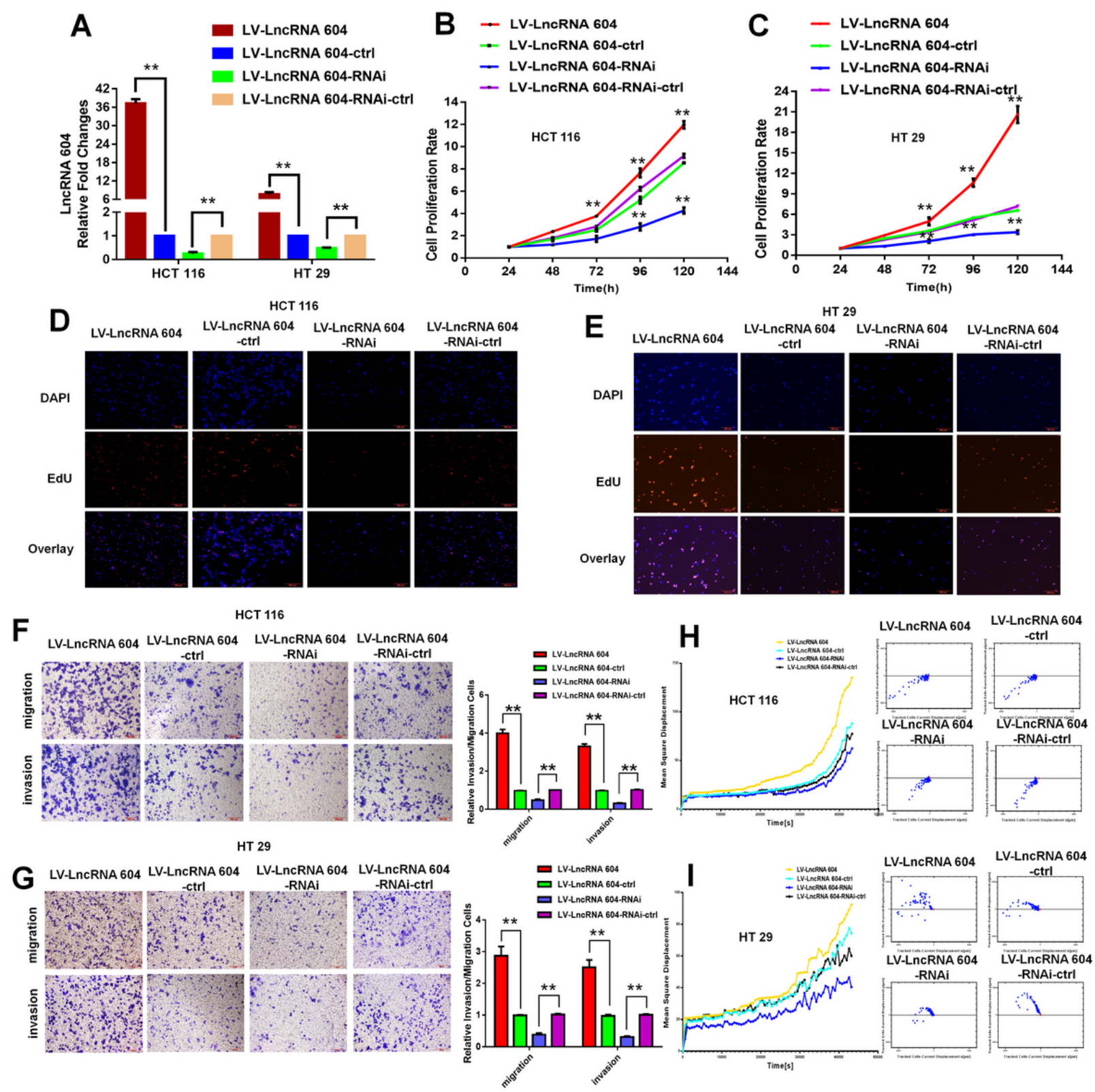

\section{Figure 2}

LncRNA 604 promoted CRC cells proliferation and metastasis in vitro. A: The effect of virus interference for IncRNA 604, the experimental cells were divided into four groups: LV-LncRNA 604; LV-LncRNA 604-ctrl; LV-LncRNA 604-RNAi; LV-LncRNA 604-RNAictrl. B, C: LncRNA 604 could promote CRC cells proliferation by CCK8 assay (B: HCT 116; C: HT 29). D, E: LncRNA 604 could promote CRC cells proliferation by EDU assay (D: HCT 116; E: HT 29). F, H: LncRNA 604 could enhance CRC cells invasion and migration by transwell assay (F: HCT 116; H: HT 29). G, l: LncRNA 604 could enhance CRC cells invasion and migration by highcontent imaging system analysis (G: HCT 116; I: HT 29). 

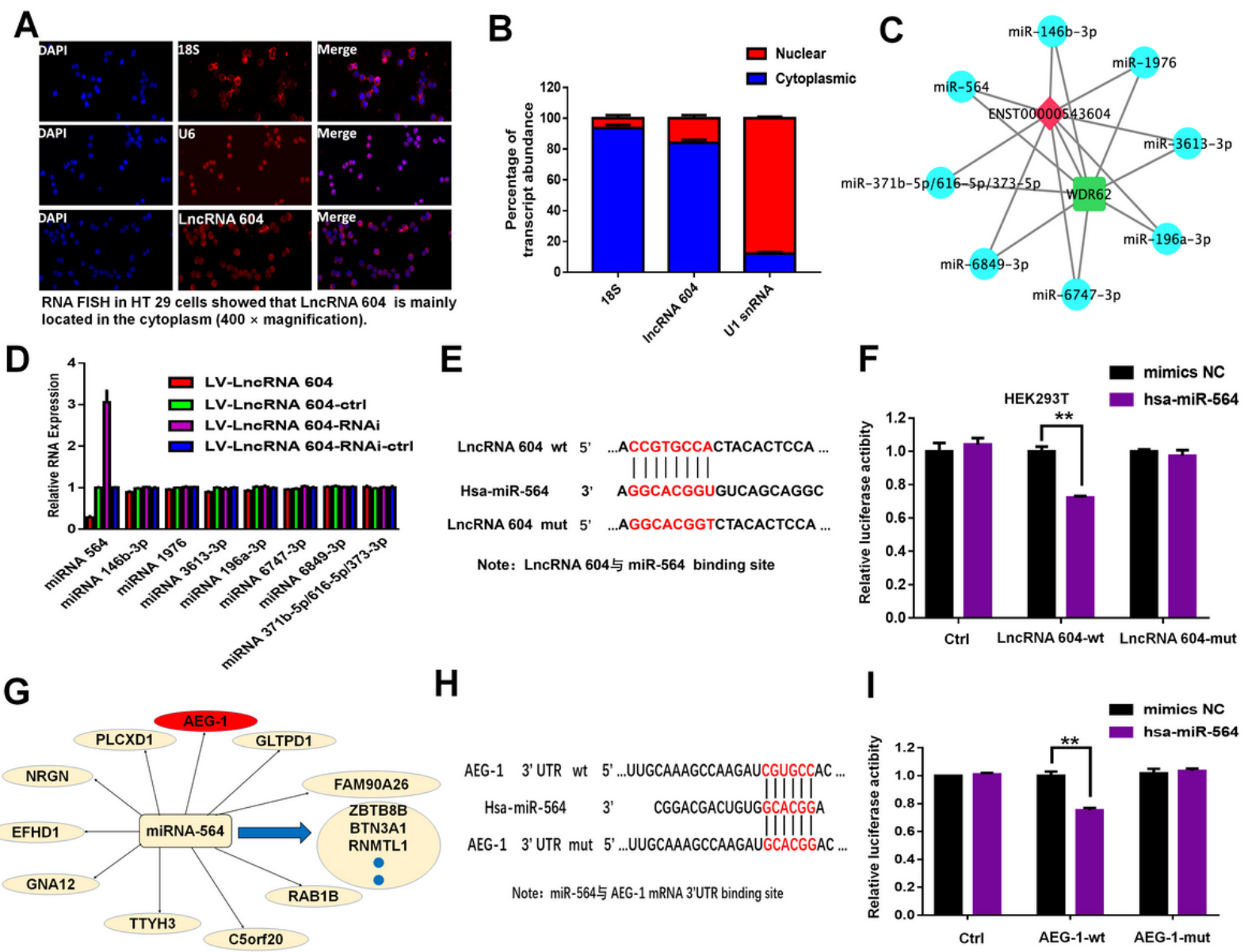

E

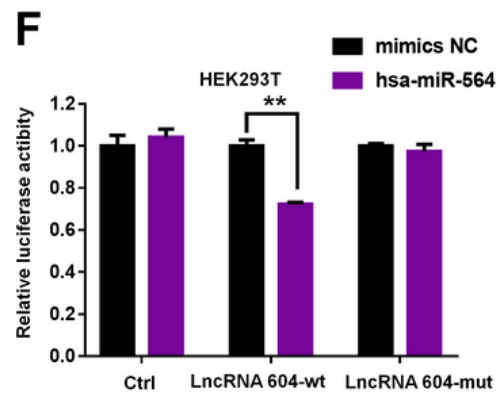

H

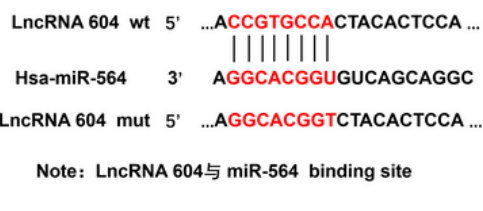

Ctrl LncRNA 604-wt LncRNA 604-mut
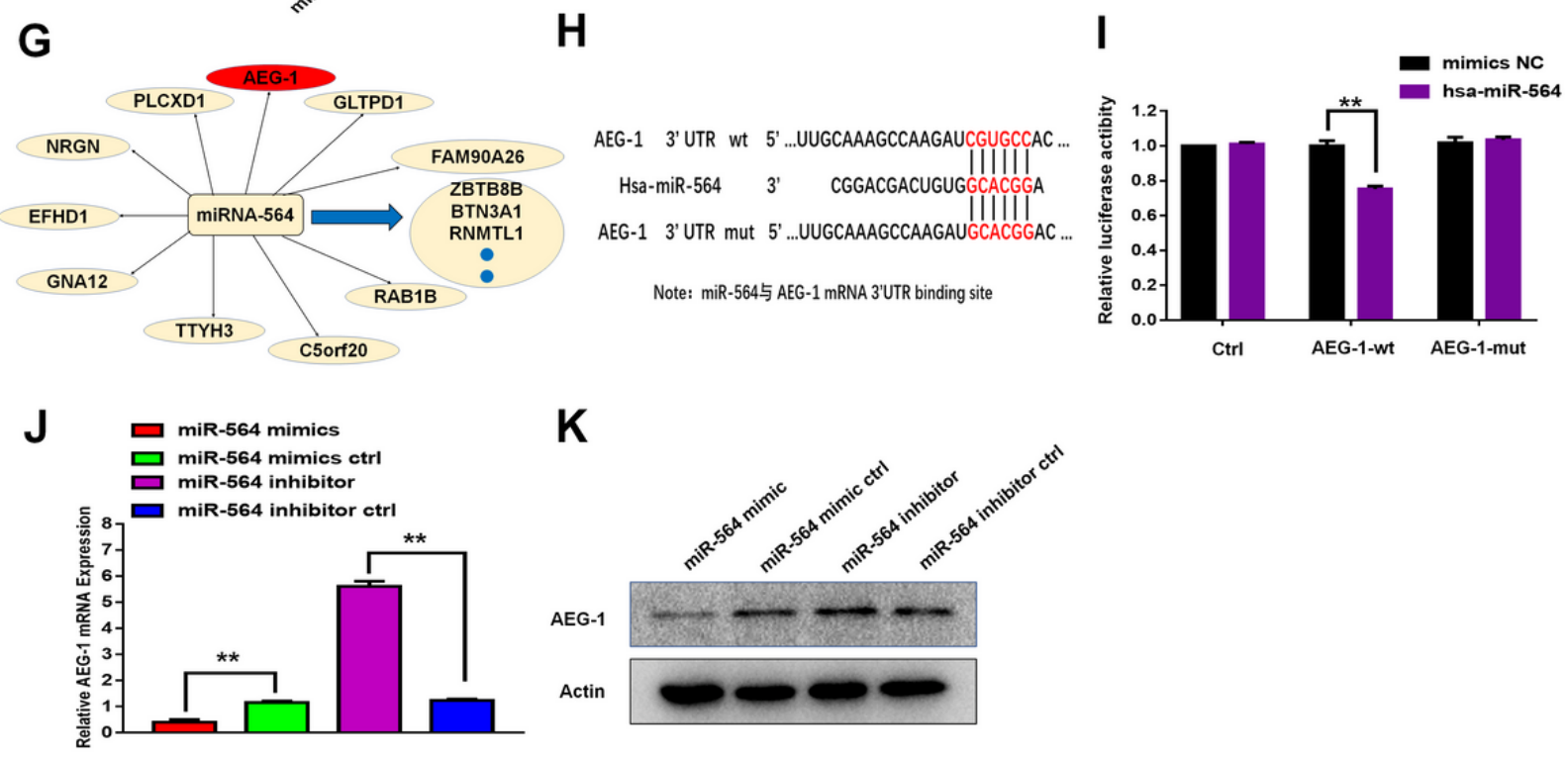

Figure 3

The mechanism of IncRNA 604 was detected as ceRNA. A: The localization of IncRNA 604 was detected by FISH assay in the cells. B: The expression of IncRNA 604 compared with the nuclear localization U1 and the cytoplasmic localization marker 18S. C: LncRNA 604 spatial signal regulation network was generated by Targetscan software. D: MiRNA 564 was regulated by IncRNA 604 by qRT-PCR in these bound miRNAs. E: The binding site of IncRNA 604 and miRNA 564. F: MiRNA 564 bounded the wild type of IncRNA 604 by the dual luciferin reporter gene. G: The putative target genes of miRNA 564 was predicted by MiRanda (http://www.microrna.org). H: The binding site of miRNA 564 and AEG-1. I: miRNA 564 mimics reduced the luciferase activity of wt 3'UTR of AEG-1, while had no effect on mut 3'TUR of AEG-1. J, K: MiRNA 564 could negatively regulate AEG-1 by qRT-PCR and WB (J: RNA; K: protein). 


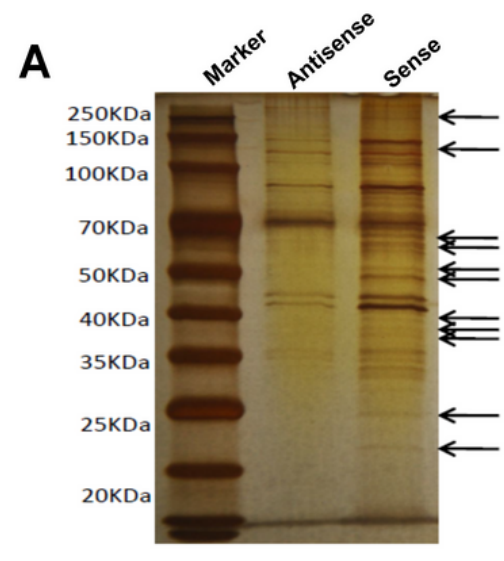

B

\begin{tabular}{cc}
\hline Gene name & Score \\
\hline TUBA4A & 193.32 \\
ZNF326 & 189.94 \\
TUBB2A & 181.96 \\
S100A9 & 154.38 \\
LGALS7 & 129.5 \\
PRSS2 & 128.02 \\
MYH14 & 121.93 \\
RPLPOP6 & 117.35 \\
RPL10L & 110.74 \\
CLIC1 & 109.94 \\
$\ldots$ & $\ldots$ \\
\hline
\end{tabular}

C

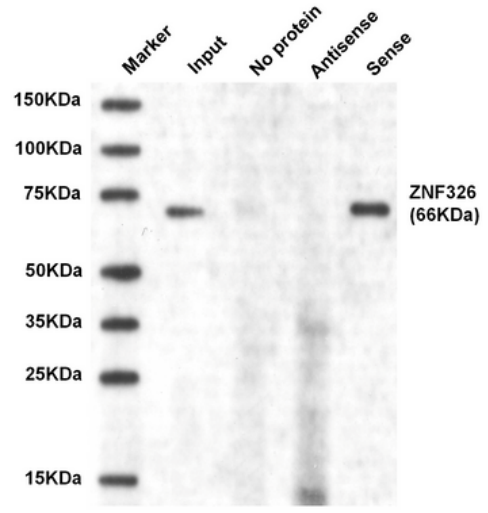

$15 \mathrm{KDa}$

E

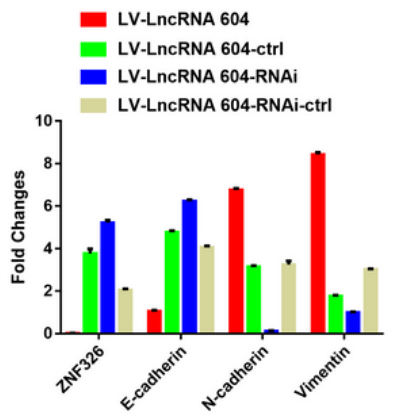

Actin
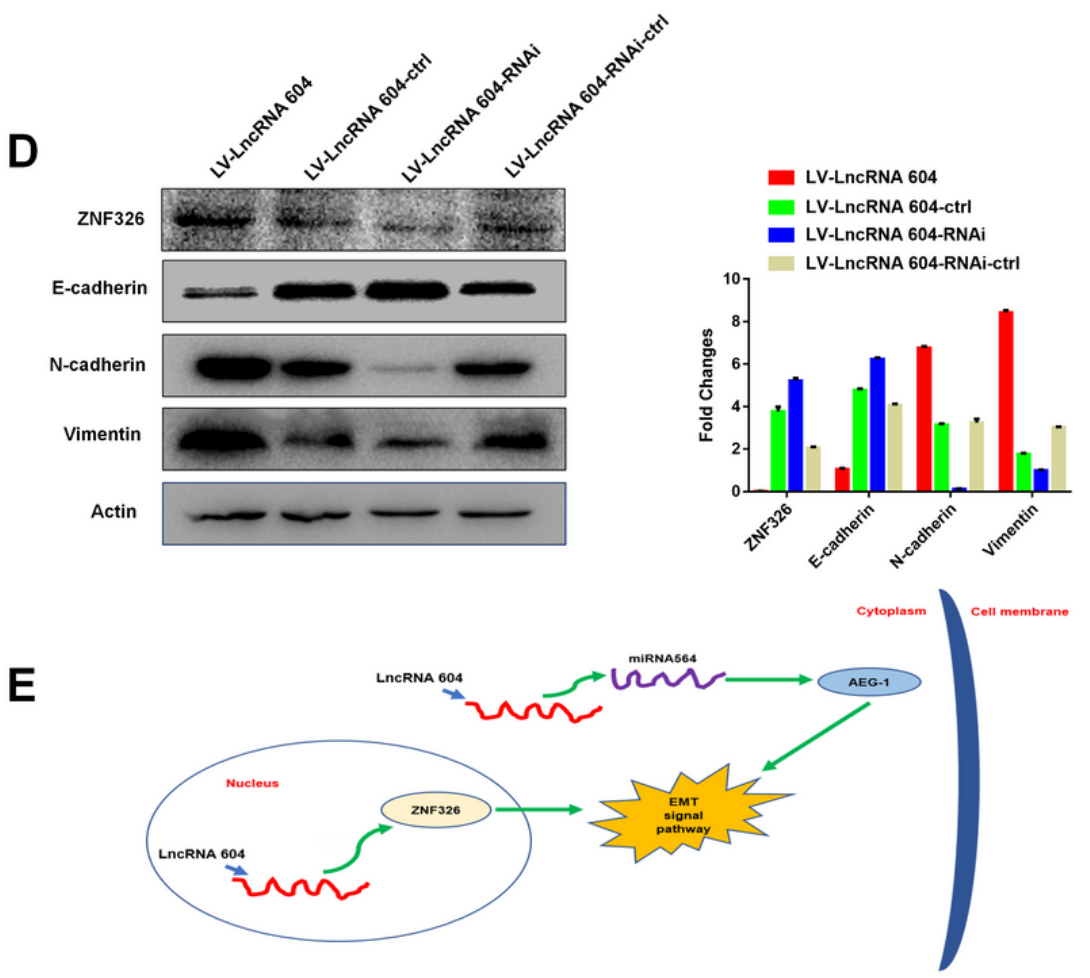

Proposed model for the regulatory mechanisms of LncRNA 604

\section{Figure 4}

The mechanism of IncRNA 604 was detected as binding nuclear transcription factor. A: The silver staining indicated that all bound proteins were pulled out by RNA pull down assay. B: ZNF326 was the second most differential protein in IncRNA 604-binding product by mass spectrometry. C: ZNF326 expression was confirmed this specific binding with IncRNA 604 by WB. D: LncRNA 604 could positively regulate ZNF326, N-cad, Vim expression and decrease E-cad expression. E: The totle mechanism signal route: IncRNA 604 could inhibit AEG-1 by combining with miRNA564 in the cytoplasm and regulate the nuclear transcription factor ZNF326 in nucleus, which could promote the occurrence of EMT and lead to CRC metastasis. 
A

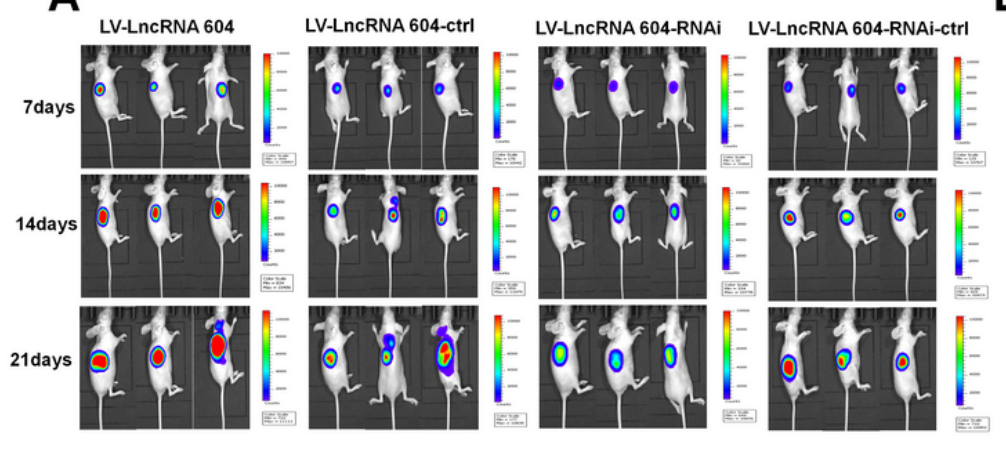

LV-LncRNA 604 LV-LncRNA LV-LncRNALV-LncRNA 604

B

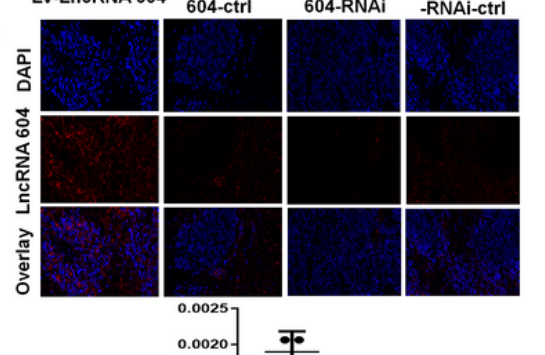

D

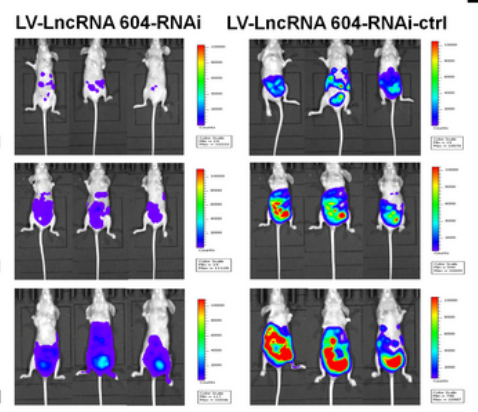

LV-LncRNA 604 LV-LncRNA LV-LncRNALV-LncRNA 604

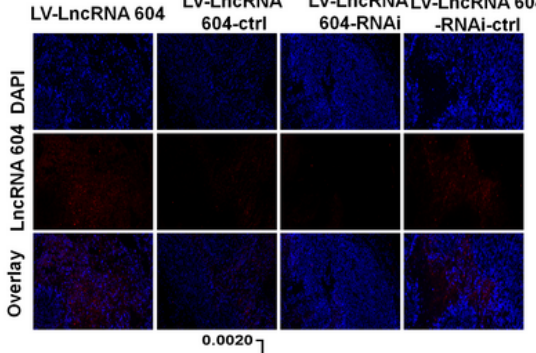

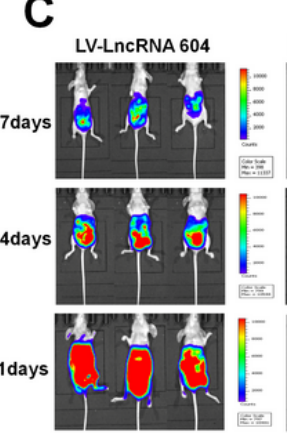

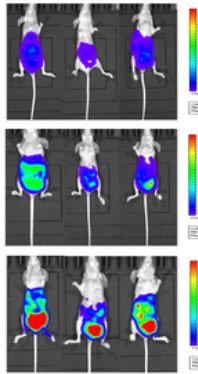

$\mathbf{E}$
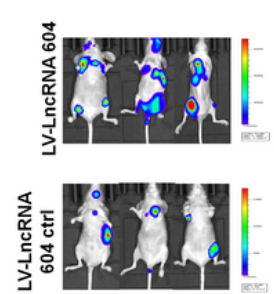
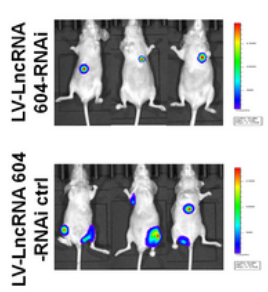

$\mathbf{F}$

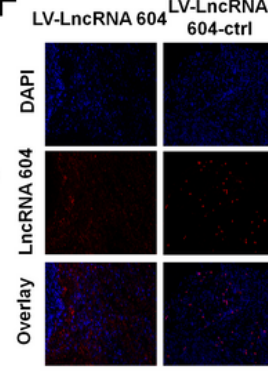

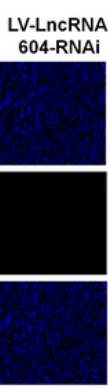

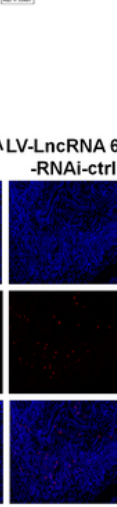

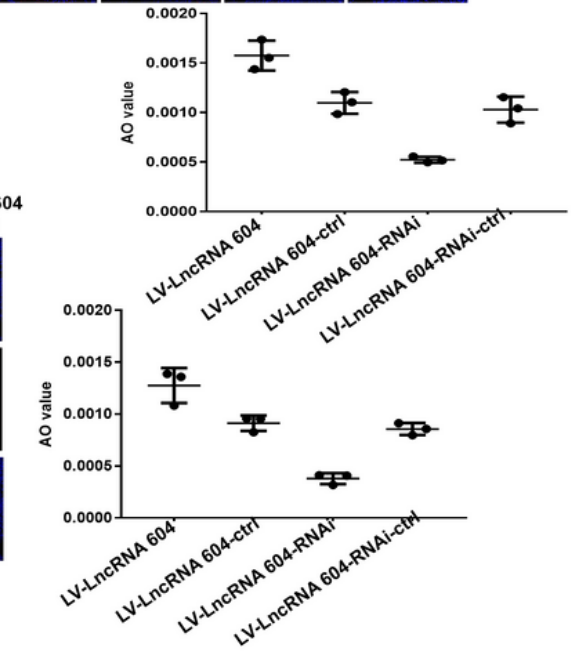

Figure 5

LncRNA 604 promoted CRC cell growth and metastasis in vivo. A: The growth of subcutaneous tumor was observed in every group by a small-animal living imaging system: tumour growth increased in LV-IncRNA 604 group, however suppressed in LV-IncRNA 604RNAi group. B: The expression of IncRNA 604 in the xenograft tumors was detected by FISH. C: Much more metastases were found in LV-IncRNA 604 group, however the LV-IncRNA 604-RNAi group was opposite in abdominal cavity metastasis model. D: The IncRNA 604 expression of abdominal metastases was consistent with cells. E: In the tail vein metastasis model, there were more multiple metastases in LV-IncRNA 604 group, however LV-IncRNA 604-RNAi group was significantly less than respective control group. F: The IncRNA 604 expression of all metastases was detected by FISH. 
A

50

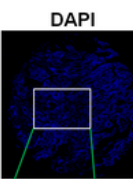

200 -
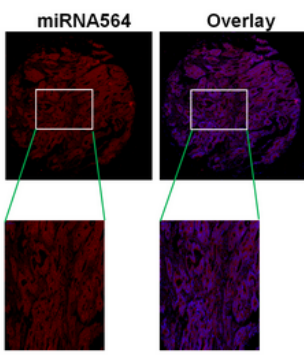

B

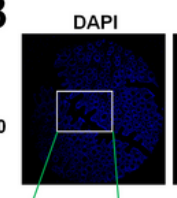

200
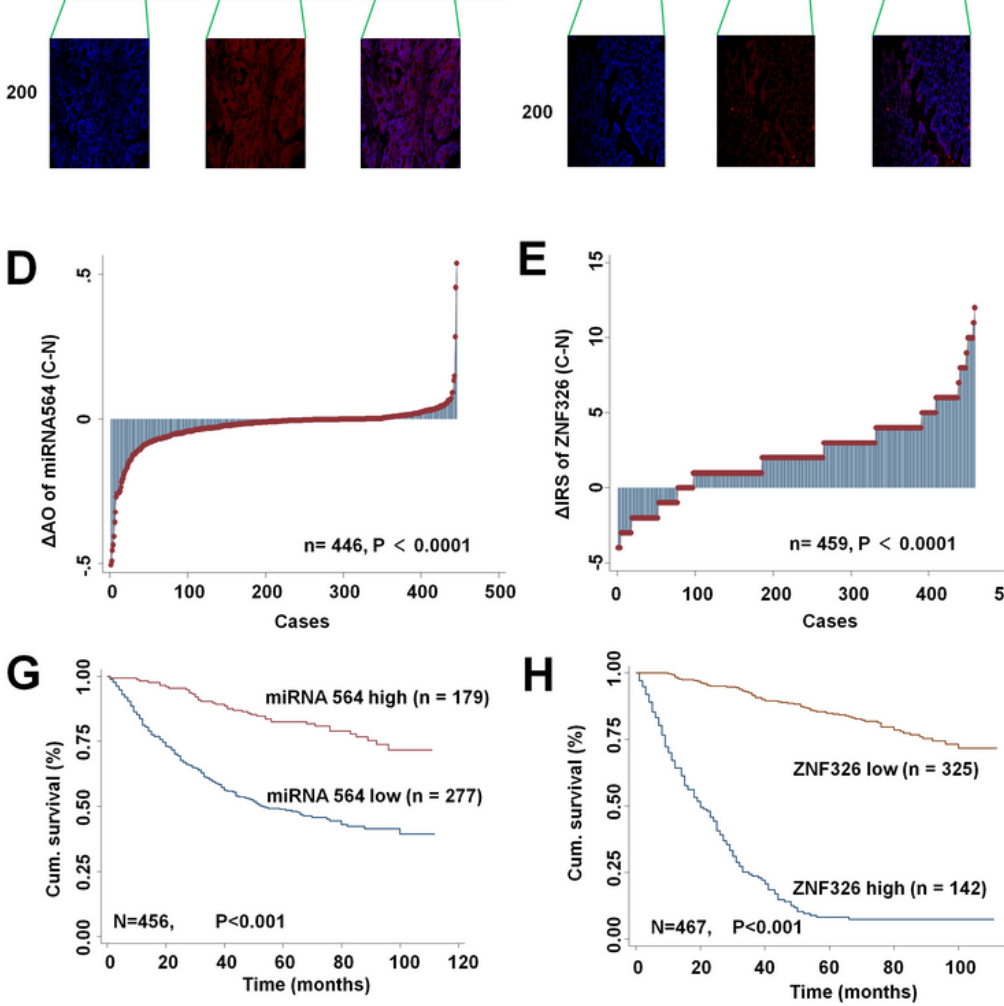

\section{$\mathbf{J}$}

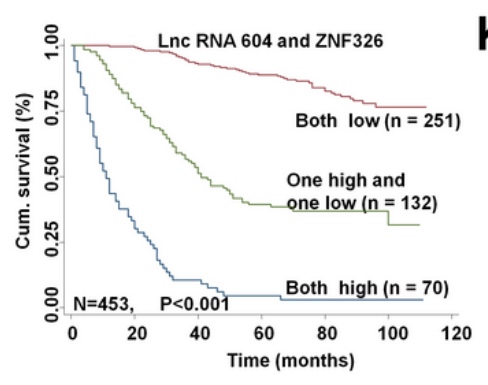

E
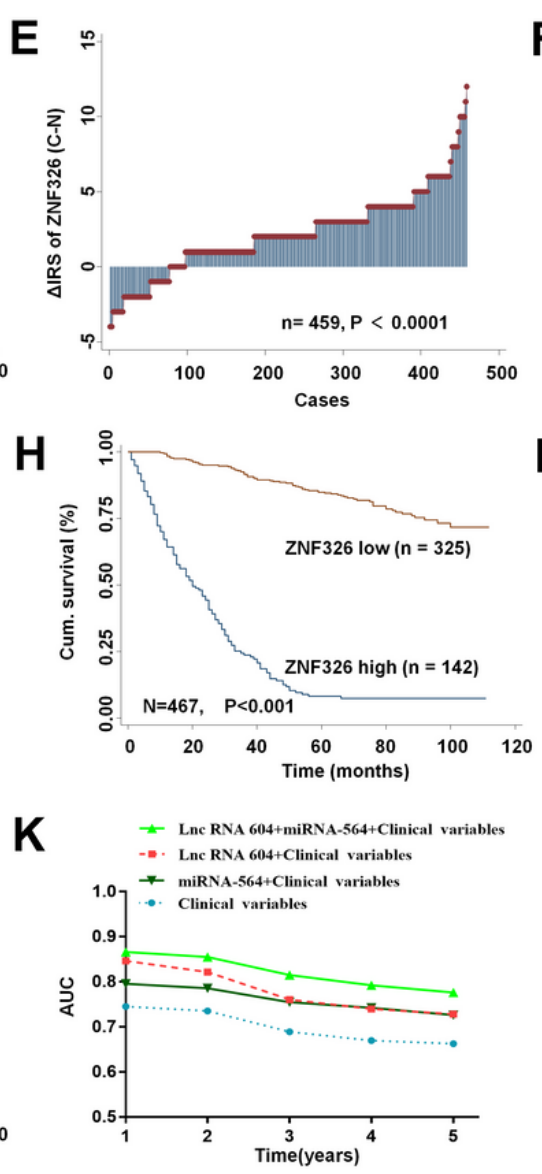

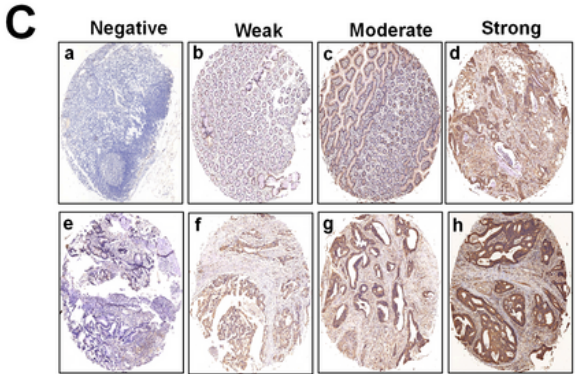

$\mathbf{F}$
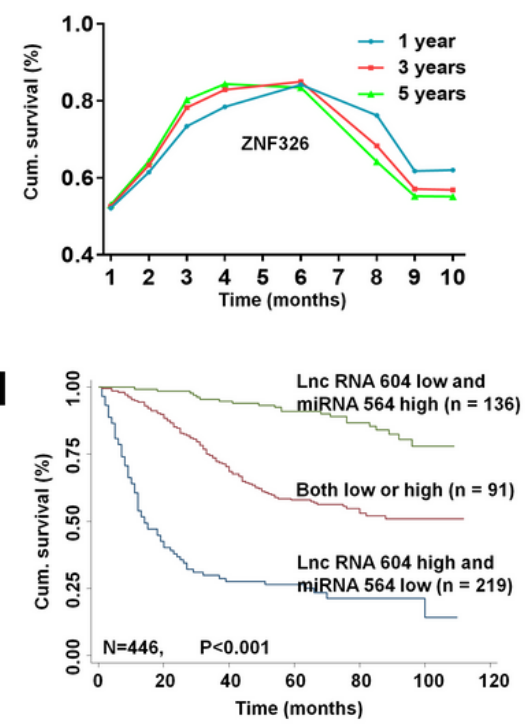

L $\quad-$ Lnc RNA 604+ZNF326+Clinical variables

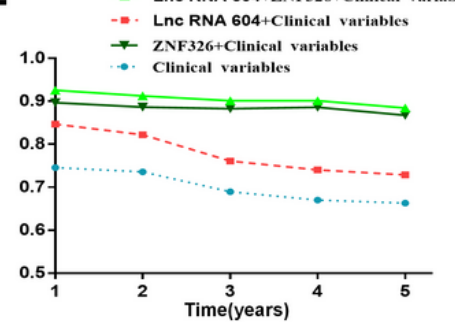

Figure 6

LncRNA 604 with its regulatory molecules predicted the prognosis of CRC. A, B: The typical pictures of miRNA 564 was detected by FISH (A:cancer; B: normal tissue). C: The typical pictures of ZNF326 was detected by IHC. D, E: Molecular expression was analyzed in tumor and normal tissues (D: miRNA 564; E: ZNF326). F: The cutoff value of ZNF326 was calculated by ROC analysis. G, H: High miRNA 564 or low ZNF326 expression had a better OS in CRC patients by Kaplan-Meier survival analysis. (G: miRNA 564; H: ZNF326). I, J: LncRNA 604 combined with its regulatory molecules had the best survival prognosis by Kaplan-Meier survival analysis (I: IncRNA 604 and miRNA 564; J: IncRNA 604 and ZNF326). K, L: ROC analysis indicated IncRNA 604 combined with miRNA 564 or ZNF326 had a synergistic effect on prognosis of CRC patient (K: IncRNA 604 and miRNA 564; L: IncRNA 604 and ZNF326). 

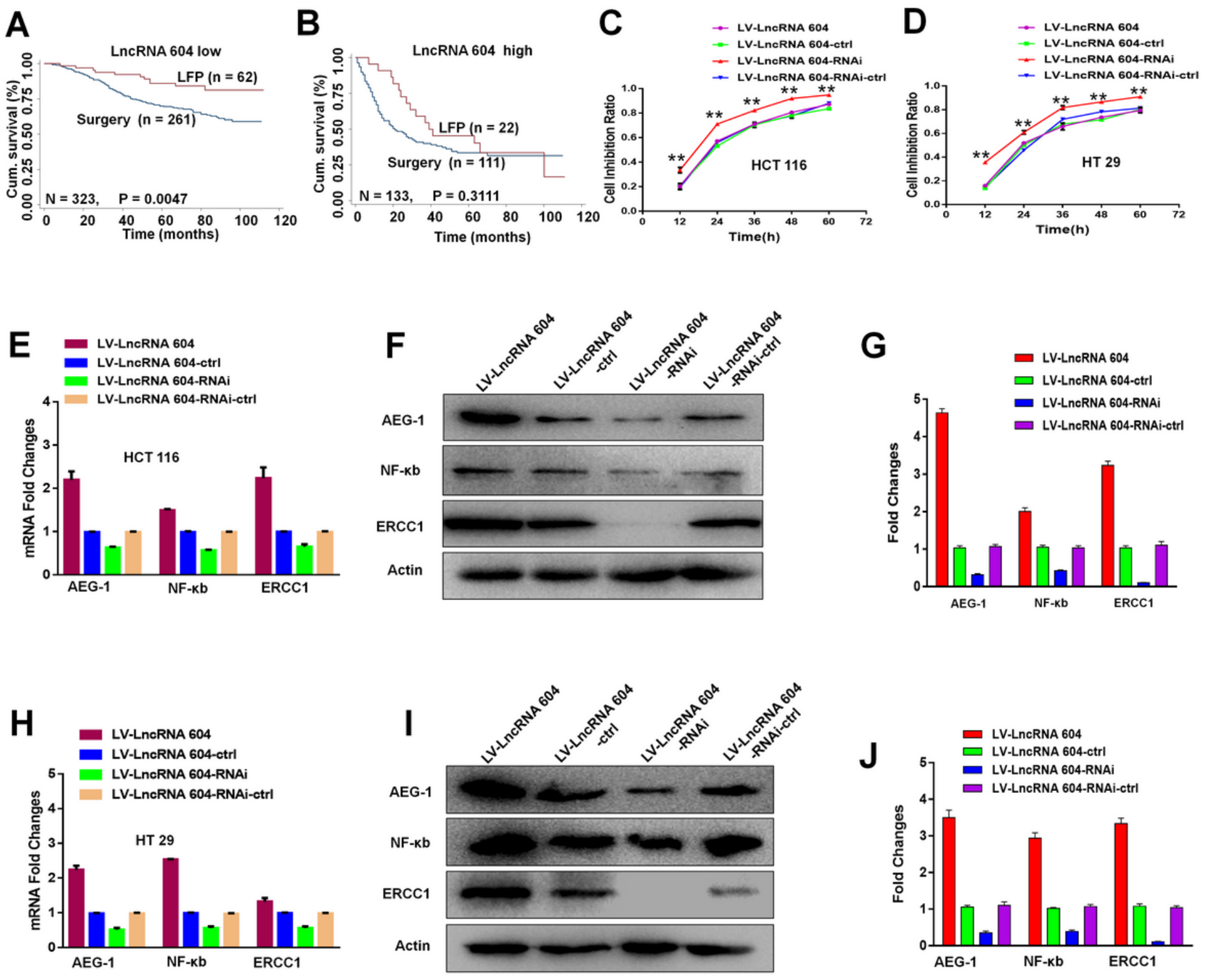

Figure 7

LncRNA 604 promoted CRC cell chemoresistance by improving the expression of AEG-1, NF-kb, and ERCC1. A, B: CRC patients with low-expressed or high-expressed IncRNA 604 who adopted postoperative LFP regimen compared with patients who received surgery alone on OS by Kaplan-Meier curve method (A: low-expressed IncRNA 604; B: high-expressed IncRNA 604). C, D: LV-IncRNA 604-RNAi CRC cells were more sensitive than control group, however LV-IncRNA 604 cells were not sensitive by CCK8 assay in vitro (C: HCT 116; D: HT 29). E, F, G: AEG-1, NF-kb, and ERCC1 in HCT 116 cells were changed with the expression of IncRNA 604 by RTPCR and WB (E: RNA; F, G: protein). H, I, J: AEG-1, NF-kb, and ERCC1 in HCT 29 cells were changed with the expression of IncRNA 604 by RT-PCR and WB (H: RNA; I, J: protein). 
A
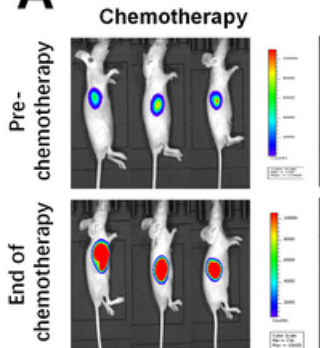

LV-Lnc RNA 604-RNA
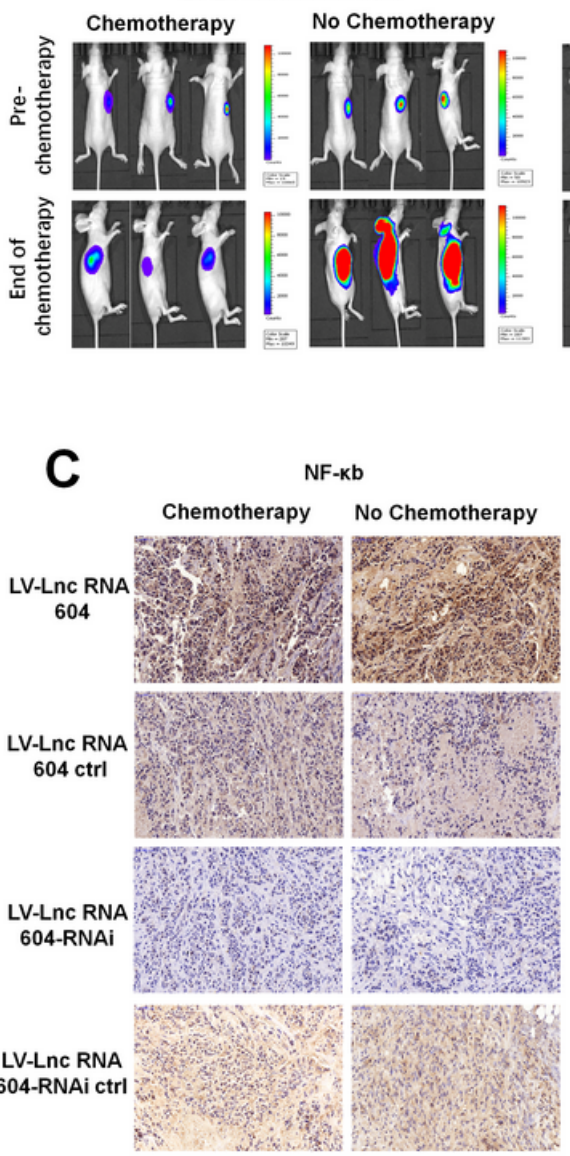

LV-Lnc RNA 604 ctrl

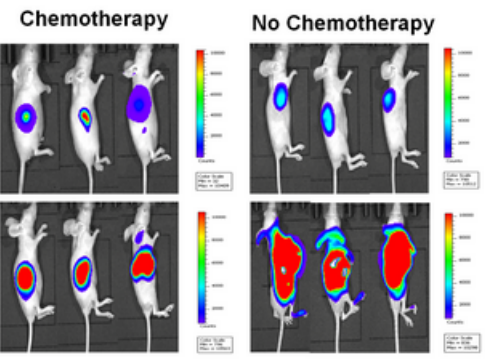

LV-Lnc RNA 604-RNAi ctrl

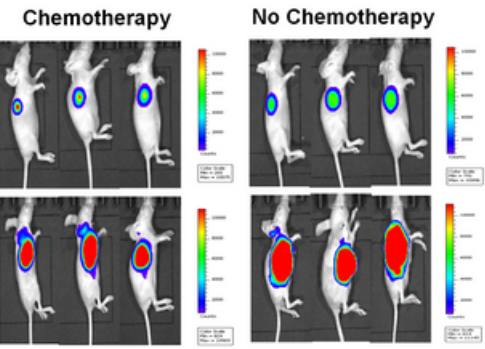

B

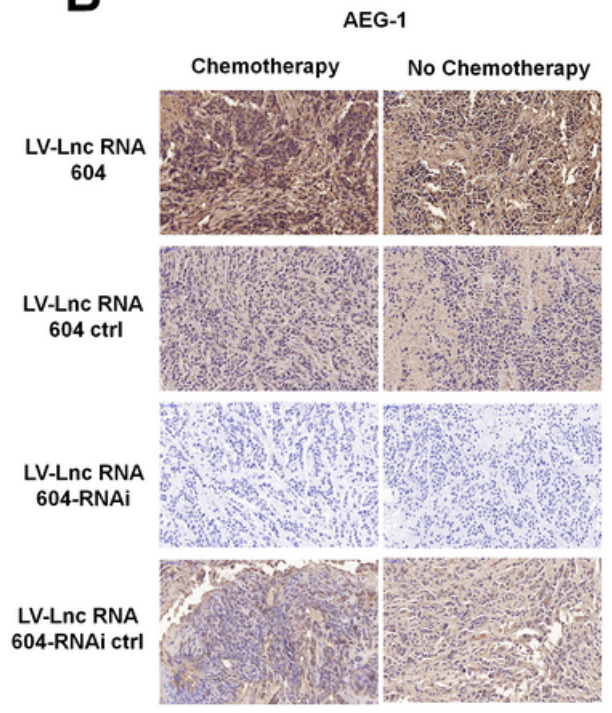

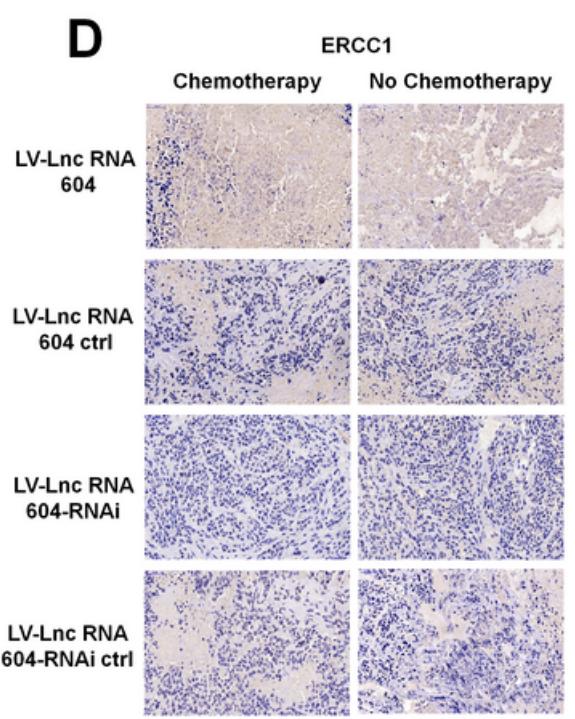

E

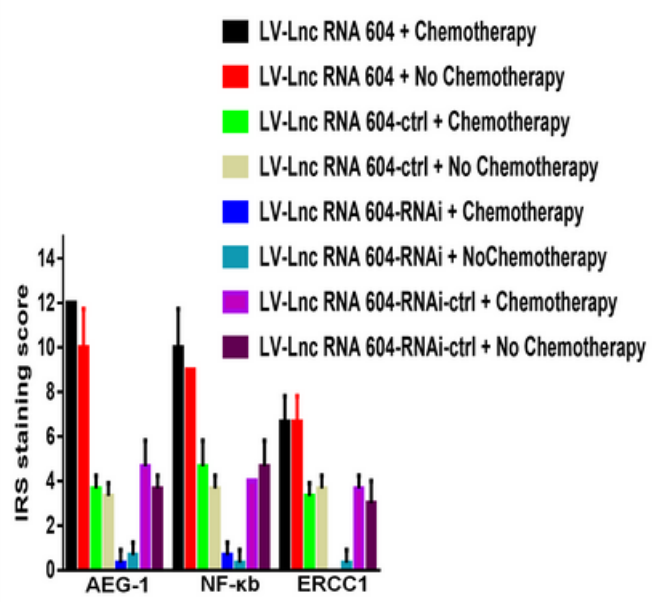

Figure 8

LncRNA 604 promoted CRC cell chemoresistance in vivo. A: The subcutaneous tumors were significantly smaller in low-expressed IncRNA 604 group while the high-expressed IncRNA 604 group failed to benefit, compared with their respective control groups. B, C, D: AEG-1, NF-kb, and ERCC1 in subcutaneous tumor were detected by IHC, the trends were the same as WB in vitro (B: AEG-1; C: NF$\mathrm{kb}$; D: ERCC1). E: The IRS staining score of AEG-1, NF-kb, and ERCC in all groups was graded.

\section{Supplementary Files}

This is a list of supplementary files associated with this preprint. Click to download.

- Tables1.docx 